\title{
Wagner and Paris: The Case of Rienzi (1869)*
}

Mark Everist

Any search for operatic crosscurrents in the second half of the nineteenth century eventually leads to a consideration of the relationship between Wagner and Paris. ${ }^{1}$ Not only does this relationship problematize the questions of institution, genre and cultural transfer that characterises any import of foreign opera into the capital, but it is overlaid with polemic, scandal, individual amour propre competing with national pride, and music reflecting events on the larger world stage. It comes as no surprise that this is a subject that has been generously treated in accounts of nineteenth-century opera, at the expense - it could be argued - of the study of indigenous French products. ${ }^{2}$ From the earliest French texts responding to Wagner's Eine Mitteilung an meine Freunde and his Oper und Drama in the early $1850 \mathrm{~s}^{3}$ to the systematic engagement of some French composers with Wagnerian stylistic techniques in the $1890 \mathrm{~s}$ and $1900 \mathrm{~s},{ }^{4}$ there is now a sufficient understanding of the subject, it might be thought, to be able to assemble a very clear idea of how the capital of the nineteenth century assimilated the composer.

There seem to be two key points in the story of Wagner and Paris: the disastrous 1861 production of Tannhäuser at the Paris Opéra, and - thirty years later - the first successful production of the composer's work there: Lohengrin in $1891 .^{5}$ These two dates apparently bookend thirty years of Wagnerian silence in Paris, broken only occasionally by literary debates between Wagnéristes and less enthusiastic critics. But this received view of the Parisian reception of Wagner is marked by the almost complete absence of any account of an equally-important moment in Wagner-reception in Paris: the production of Rienzi that ran from 1869 to $1870 .{ }^{6}$ Indeed, in the popular mythology that surrounds the understanding of the subject, the event has been ignored in favour of the production of Tannhäuser at the Paris Opéra in $1861 .^{7}$ It is not hard to see why: twentieth-century German scholars were quick to identify the 1861 disaster as a Tannhäuser-Skandal as a way of explaining away the event as a largely Parisian aberration in a world in which the Wagner juggernaut had crushed most opposition. ${ }^{8}$ And a really rather successful production of another opera by Wagner in 1869 that permitted a cooler, more sober, view of the composer in Paris, simply did not fit this historiographical trajectory.

The 1869 performance of Rienzi is not the only casualty of scholarly obsession with Wagner's difficulties with Le Tannhauser - as the work was known in Paris - eight years earlier. Much of the journalistic writing about Wagner that goes beyond the Tannhauser débâcle is still incompletely understood. The more extreme positions pro and contra 
expressed in the professional music press, with the anti-Wagnerians François-Joseph Fétis and Paul Scudo ${ }^{9}$ in opposition to the pro-Wagnerians Adolphe Giacomelli and Auguste de Gasparini, enjoy a measure of understanding. ${ }^{10}$ But there are other emergent literary trends in the 1860 s, some in the wake of the 1861 Tannhaüser, others not - not only such texts as those by Charles Pierre Baudelaire and Jules-François-Félix Fleury-Husson (Champfleury) most obviously, ${ }^{11}$ but also those of such other pro-Wagnerians as Léon Leroy, Édouard Schuré, Judith Mendès (Gautier) and others. ${ }^{12}$ These were the people who made pilgrimages to Vienna to hear Wagner conduct excerpts from Das Rheingold and Die Walküre in 1862, and to Munich to witness von Bülow conducting the premieres of Tristan und Isolde in 1865 and Die Meistersinger von Nürnberg in 1868; they were active promoters of Wagner in the 1860s. ${ }^{13}$

Other gaps surround modern understanding of the performances of Wagner in concert situations in the $1860 \mathrm{~s}$; this one of the ways in which detractors or partisans could hear performances of the composer's music between 1861 and 1869, and is one of the reasons why the performance of Rienzi at the end of the decade is so important: it gave musicians a chance to think about something other than the tiny selection of extracts that could be heard either at the Concerts populaires or - much more rarely - at the now-venerable Société des concerts $d u$ Conservatoire, and to experience Wagner in the opera house rather than the concert hall. ${ }^{14}$ The 1869 production of Rienzi that took place at the Théâtre-Lyrique was experienced in the context both of Le Tannhauser debacle and of other Wagnerian pressures developing in the 1860s. It was furthermore a production largely unrevised - in comparison with Le Tannhauser - of a work that was nearly 30 years old which contrasted with the presentation of the teenage Tannhäuser in Paris in 1861. By 1869, but there was much less of the acrimony and partisanship that had characterised - and perhaps animated - the failure of the production of Le Tannhauser in 1861. The 1869 Rienzi allowed, for the first time, a public discussion of the tradition, values and impact of Wagner in Paris in which opposing voices could be heard, appreciated and evaluated.

Jules-Etienne Pasdeloup took over the management of the Paris Théâtre-Lyrique in 1868. One of his first innovations was the production of Rienzi, which premiered on 6 April 1869 and ran for 38 performances until Pasdeloup's management collapsed in bankruptcy in early $1870 .{ }^{15}$ Although Wagner was not present for the production, he had been working extensively behind the scenes with Pasdeloup who had received advice from the composer in Lucerne before the premiere. The significance of this production for Paris, for its audiences and fourth estate was enormous; it permits the examination of such broad issues as pamphleteering, texts, the relationship between concert and stage music and the inscription of 
Wagner and his music in Franco-Prussian and Franco-Bavarian foreign policy in the 1860s, leading up to the Franco-Prussian war and the end of the Second Empire.

\section{Rienzi in Paris: The Théâtre-Lyrique}

Le Tannhauser had been produced at the Théatre Impériale de l'Opéra - the so-called Paris Opéra - which had been on the rue le Peletier since 1821 and which saw all the major premieres of grand opéra from Auber's La muette de Portici (1828) to Meyerbeer's L'africaine (1865). This half century of activity had formed one element of an operatic culture which also included the Opéra-Comique - similarly hosting works from Boieldieu's La dame blanche (1825) to Bizet's Carmen (1875) - and the Théâtre Italien. These three organisations - the Opéra, the Opéra-Comique and the Théâtre Italien - accounted for the most prestigious stage music in the city. ${ }^{16}$

But throughout the century, there had been movements to set up what was routinely called a 'troisième thêâtre lyrique', third after the Opéra and Opéra-Comique (in this chauvinistic reckoning, the Théâtre-Italien did not count). So alongside the Opéra and OpéraComique were, from 1824-28 the Théâtre Royal de l'Odéon, from 1838-1840 the Théâtre de la Renaissance, the Opéra national from 1847-48, and from 1851 the opera house that gave a home to Rienzi, the Théâtre-Lyrique. All these institutions were set up, at least in part, to provide a platform for Prix de Rome laureates returning from their sojourns in Italy and who found it difficult to gain access to either the Opéra or Opéra Comique. In reality, the opera houses were all more concerned with broadening their repertory well beyond these limits: in the case of the Odéon with public-domain opéra comique; and in the case of the Théâtre de la Renaissance with two specially invented genres: the vaudeville avec airs nouveaux ${ }^{17}$ and the opéra de genre. ${ }^{18}$ Alongside these attempts, the presentation of foreign operas in French translation was critical to the survival of each troisième théâtre lyrique. Examples were Weber's Der Freischütz as Robin des bois at the Odéon in $1824{ }^{19}$ and Donizetti's Lucia di Lammermoor as Lucie de Lammermoor at the Renaissance in 1839.

The reason for this state of affairs was the licensing system that had been in place since 1807 , and that attempted to assign a single genre to each opera house in the city. By the time the Théâtre-Lyrique received its licence in 1851, much was beginning to unravel and the Théâtre-Lyrique was one of the main beneficiaries of this loosening of the reins of generic power. Although it was not originally permitted to mount the current repertory of either the Opéra or Opéra-Comique, it could certainly put on productions of new works in a way that would have made the directors of the Odéon or Renaissance green with envy twenty or thirty years earlier. Gounod's Faust, Bizet's Les pêcheurs de perles and Berlioz's Les Troyens 
were all premiered at the Théâtre-Lyrique. In addition, and in the same way as the Odéon and the Renaissance, it was permitted to produce translations and arrangements of Italian and German opera: the French translation of Rienzi came at the end of a series of successful translations of the works of Weber, Mozart and Verdi. ${ }^{20}$

Opera at the Odéon, the Renaissance and the Opéra National all collapsed in financial ruin, and the Théâtre-Lyrique had similarly bankrupted Edmond and Jules Seveste, Emile Perrin, Pierre Pellegrin, Charles Réty and Léon Carvalho before Pasdeloup took over the opera house in August 1868. ${ }^{21}$ Pasdeloup's Société des Junes Artistes du Conservatoire Impérial de Musique had already represented an alternative voice to the Société des Concerts du Conservatoire from 1853 onwards, and his Concerts populaires, given in the Cirque Napoléon throughout the 1860 s to audiences rising to 5000 were of incalculable significance. The repertory of Concerts populaires aligned itself closely with the Germanophone tastes of its conductor - the Paris premieres of Schuman's first and third symphonies were given under his direction, for example - but it was Wagner who benefitted most from his enthusiasm. ${ }^{22}$ The choice of works was largely determined by the extracts that Wagner himself had performed in Paris just before the Le Tannhauser production of 1861: the overture to Der fliegende Holländer, the overture, march and pilgrims chorus from Tannhäuser, the prelude to Tristan und Isolde, three extracts from Lohengrin, and so on. ${ }^{23}$ For some of the $1860 \mathrm{~s}$, however, Wagner was almost completely absent; there were no performances at all in the 1861-2 and 1863-4 seasons, and only a single work in the 1862-3 season. The composer reached his greatest popularity in the 1867-68 to 1869-1870 seasons during each of which there were nine concerts including works by Wagner. ${ }^{24}$ Not having Wagner in Paris certainly helped the success of these extracts, and the distance between these concerts and the noise surrounding the musique de l'avenir that had been so disadvantageous to Wagner and the 1861 Le Tannhauser production also assisted. ${ }^{25}$ But for the thousands who flocked to Pasdeloup's concerts populaires, these performances were an important backdrop to the drama played out as Rienzi came to Paris at the end of the decade. ${ }^{26}$

Pasdeloup had no experience of music for the stage when he took over the ThéâtreLyrique in 1868, and when he expressed his interest in managing the theatre in a letter to the Ministre des Beaux-Arts he made it clear that he was going to continue to promote his concerts populaires at the same time as directing the Théâtre-Lyrique. ${ }^{27}$ His management at the latter institution barely lasted eighteen months, and was declared by the Ministère des Beaux-Arts to have been largely ineffective both in artistic and financial terms. ${ }^{28}$ While the financial judgement was incontrovertible, the artistic conclusion was more open to question.

The repertory of the $1868-69$ season is given as table $1 .{ }^{29}$ 
Table 1

No less than eight revivals out of a total of eleven works included two foreign classics:

Rossini's Il barbiere di Siviglia, in Castil-Blaze's 1819 translation and arrangement that had been a staple of the Théatre-Lyrique since its opening, and Mozart's Don Giovanni in a new translation and arrangement that dated from the 1866 Wunderjahr when three new productions of the opera were mounted at three different Parisian opera houses within the space of three months. ${ }^{30}$ Two Parisian classics were Gluck's Iphigénie en Tauride from the Opéra and Méhul's L'irato from the Opéra-Comique. Of the two works by Adam, La poupée de Nuremberg had been written for the Théâtre-Lyrique and had been playing there as long as Le barbier de Séville. On the other hand, Le brasseur de Preston - like Halévy's Le val d'Andorre - had been imported from the Opéra-Comique, but unlike the Halévy, this was the first time Le brasseur de Preston had appeared at the Théâtre-Lyrique. The translation of La traviata as Violetta had been known at the Théâtre-Lyrique for four years before Pasdeloup programmed it, and had been a standard item at the Théâtre-Italien since $1856 .^{31}$ The two world premieres were very different. Ernest Guiraud came reasonably close to fitting the bill as a Prix de Rome laureate who had recently returned from Rome, but he had already had a success with his opéra comique Sylvie in 1864 (he had won the Prix de Rome in 1859 and had spent considerable time in Italy in the company of Bizet). ${ }^{32}$ By contrast, Ernest-HenriAlexandre Boulanger had won the prize in 1835, by the late 1860s was an established figure, and in the same year as the premiere of Don Quichotte he was made Chevalier de la Légion d'honneur and Professor of Singing at the Conservatoire two years later. Don Quichotte was his ninth opera to be produced. ${ }^{33}$

Rienzi fits logically into this repertory. Like Le barbier de Séville and Don Juan it is a translation, and it is a contemporary of Le brasseur de Preston, Le val d'Andorre and La poupée de Nuremberg from the long 1840s; Wagner's view of being put alongside Adam and Halévy into the repertorial framework of 1869 can only be conjectural, but may be compared with his alliance with Donizetti thirty years previously, when both composers had suffered as a result of the collapse of the Théâtre de la Renaissance in early $1840 . .^{34}$ In terms of its ambitions and musical dimensions, however, Rienzi fits better with works premiered the following season, translations of Verdi's Un ballo in maschera as Le bal masqué and Balfe's The Bohemian Girl as La bohémienne and especially with Victorin Joncières' newlycomposed Le dernier jour de Pompeii. But of course, it is more logically read as a result of a sustained commitment to Wagner in concerts going back a decade by Pasdeloup himself.

Trying to identify which version of Rienzi Paris heard in 1869 is no mean feat. The work was conceived at a point in Wagner's life when his operatic ambitions stretched no further than Parisian grand opéra; Rienzi was therefore - like most operas by Meyerbeer or 
Halévy for example - overcomposed in the expectation that parts would have to be excised for dramatic purposes. ${ }^{35}$ The operas with which Wagner was most intimately connected while writing Rienzi - Donizetti's La favorite and Halévy's La reine de Chypre behave in exactly this way, and it is no surprise that he would emulate their conventional practices. ${ }^{36}$ Once he had distanced himself from grand opéra in the early 1840s, Wagner then started to become more seriously concerned about the textual status of all his works so that when he became involved with grand opéra again in the late 1860s, he exhibited a strangely obsessive concern with the text of Rienzi, a work that was never really intended to support such an interpretation.

There had been talk of a production of Rienzi in Brussels in 1862, and Wagner had sent an annotated copy of the score to Jules-Louis Guilliaume in order to have it translated. ${ }^{37}$ Wagner writes extensively of a grande partition d'orchestre autographiée to his Parisian correspondents, and he is probably referring to the same annotated copy of the Furstenau print of the full score that Wagner had sent to Guilliaume and to which the latter had appended a first-draft translation of the work into French. ${ }^{38}$ It seems clear that this score - once it had finally arrived in Paris from Brussels - which it must have done by the end of January 1869 at the latest - served as the exemplar both for Pasdeloup's performance material and for the two printed editions by Flaxland and Durand-Schœnwerk. ${ }^{39}$

Questions of textuality came to a head with the published French score of the opera released by Gustave-Alexandre Flaxland in $1869 ;{ }^{40}$ this contained 458 pages in its first issue but was re-issued in an expanded form with the same title page and plate number later the same year by Durand-Schœnwerk, who had by then purchased Flaxland's business. ${ }^{41}$ The details are unclear, and Wagner's exact involvement opaque, but the additions to the DurandSchœnwerk edition (which ran to 500 pages) show all the signs of an attempt to reinstate material that had been omitted from the earliest edition of the Furstenau 1845 full score, and from earlier productions. ${ }^{42}$ There remained therefore a continuing tension between the flexible, mobile, origins of the work in the early 1840s and Wagner's greater concern for textual fidelity in the later 1860 s.

Surviving documents for the 1869 production consist of the published libretto that accompanied the premiere, the censors' libretto and a single document from the performance material. The two versions of the libretto reveal much of the attitude towards the text - both musical and poetic - of the Paris version of the opera. ${ }^{43}$ The censors' libretto was submitted by the Théâtre-Lyrique on 22 December 1868 and was approved with some changes on 28 December the same year. One of the censors had systematically gone through the entire libretto removing all references to Rome and anything that might conceivably be associated with the papacy. So, for example, in the act I introduction when Orsino and Colonna defy the 
Papal legate Raimondo and the former orders 'Va! Mon frère, Lire ta messe', the censors' libretto proposes a change to 'Va! Mon frère, Parler à d'autres'. ${ }^{44}$ Similarly, shortly afterwards in his opening solo, Rienzi laments the fact that 'Rome chancelle, hélas! mal affermie', and this was changed by the censor into 'Déjà succombe, hélas! notre Patrie' ${ }^{45}$ What is striking about these changes is that they were ignored in the production itself, since the printed libretto and the published score both preserve the original uncorrected text. ${ }^{46}$ But when later in Rienzi's monologue the censors proposed a change from 'Rome grande et libre' to 'La cité grande et libre', the change was accepted and found in all published material. ${ }^{47}$ Why this change should be accepted while others were not is unclear. Ostensibly, the change removes the specific reference to Rome with mention of a generic city, but this strategy is completely undercut by the following lines: 'La cité grande et libre / Où chaque citoyen régnait au bord du Tibre! / Perfides! Répondez! Reste-t-il un Romain?'; the claims to (generic) liberty are immediately followed by specific references to the river on which Rome stands. ${ }^{48}$ The censors' libretto and the Théâtre-Lyrique's response to the censors' proposed changes are full of such inconsistencies.

It is however easy to sympathize with the censors in their concern for avoiding reference to the city of Rome or the Papacy. By late 1868, France was maintaining a garrison in Rome to protect the Pope which had been there since the battles of Magenta and Solferino in 1859; the garrison was essential to protecting Papal interests, given the assimilation of the papal states into the newly-emergent Italy of the 1860s. This, coupled to French Catholics' hostility to Napoléon III's reluctance to challenge the fate of the papal states, meant that any kind of theatrical destabilisation of Rome and the papacy was to be discouraged. But this still does not clarify how the Théâtre-Lyrique was able to escape censure for not adhering to the censors' strictures. However, they may be explained by changing attitudes to French foreign policy vis-à-vis Italy and Rome between December 1868 and April 1869. Such references might have become less critical than that had originally been thought, as France would withdraw its Roman garrison after the Franco-Prussian War, but that was not a foreseeable event in early $1869 .^{49}$

The single survival from the performance material is extremely fortunate, since it consists of a marked-up copy of the chorus score. ${ }^{50}$ This consists of all the chorus parts, together with a piano score for those numbers in which the chorus in involved; in addition, it has lengthy cues, and - more importantly - the numbers of bars rest, which indicates especially in finales and larger concerted numbers - how much, if anything, Wagner permitted to be cut. It was presumably prepared for rehearsals directed by the chef des chœurs. There is nothing, however, in this document that gives any indication about cuts in the overture, the terzett (no 2; Adriano, Irene, Rienzi): 'O Schwester sprich, was dir geschah' 
/ 'Qu'ont-ils donc fait', the Duett (no. 3; Adriano, Irene): 'Er geht und läßt dich meinem Schutz' / 'Si le destin sévère', the Szene und Arie (no. 9; Adriano): 'Gerechter Gott! So ist's entschieden schon!' / 'O tendre rêve de ma vie', and everything except the finale - 'Herbei! Auf, eilt zu uns' / 'Venez, venez' - in act v.

The chorus score, coupled to commentary in the press, permits the identification of three types of modification to the score. The first consists of cuts that had been conventional in performances of the version of the work with a German libretto dating back to its 1842 premiere; these were probably sanctioned by Wagner himself. The second comprises cuts made by the Théâtre-Lyrique as it assembled the production in the weeks before the April 1869 premiere, and which might well not have been approved by Wagner. The third type of change are those made after the premiere, and prompted by the response in the press; it is almost certain that Wagner did not authorise, and would probably not have approved of, these changes.

Examples of the first type of modification are easily identifiable in those numbers preserved in the chorus score because they were simply not copied and their omission was clearly part of the planning of the production from an early stage, probably from as soon as Pasdeloup had met Wagner in Lucerne. In the introduction to act iii, bars 59-184 are not copied and were presumably cut, for example. ${ }^{51}$ These are the lengthy appeals on the part of the chorus, led by Baroncelli and Cecco, for Rienzi to appear, and were not only cut in many performances from the 1840s onwards but were not even copied in the first edition of the opera by Furstenau in $18444^{52}$ This is one of the examples where the first 1869 Flaxland print reproduces exactly what was performed at the Théatre-Lyrique - and therefore suppresses this passage $^{53}$ - but where the second Durand-Schœnwerk 1869 print reinstated, presumably at Wagner's behest, the bars in question. ${ }^{54}$

More complicated are the changes made by the Théatre-Lyrique for the performance itself. The introduction to act iii provides an example. The chorus score provides a fully copied version of bars 217-252, and these bars are found in both versions of the printed Flaxland / Durand-Schœnwerk score. However, these bars - the last before the final stretto were removed (either by crossing out in blue crayon or by sewing pages together to conceal the bars that were cut). Wagner must have expected these bars to have been included in the performance, but it seems likely that the changes were made by Pasdeloup himself to accelerate the action towards Adriano's aria of self-reproach and misery.

What the chorus score does not reveal are the changes to the score after the premiere, especially after the second performance. Although Charles Bannelier's otherwise balanced review of the work exaggerates when he claims that more than a third of the work was 
suppressed at the Théâtre-Lyrique, ${ }^{55}$ Johannès Weber reveals much when he makes clear that both duets for Irene and Adriano - just before the first and fifth act finales - were excised. ${ }^{56}$ Whether the excision of the act $\mathrm{v}$ duet was the result of discussions between Pasdeloup and Wagner or of changes made after the premiere is something to guess at, since there is nothing in the performance material to indicate even whether the numbers were even copied, although Rémy Fasolla commented on the act i duet on 11 April, so this at least must have been a casualty of the cuts made after the second performance. ${ }^{57}$

To judge from the commentary on the production which claimed that the chorus was not only predominant but overwhelmed the rest of the vocal and instrumental forces, it might be expected that the major cuts to the work avoided the choral writing. Although this is certainly the case with the two duets just mentioned, the cuts within numbers identified in the chorus score affect widely different types of material. Beyond the conventional cut in the act iii introduction already mentioned, a 35-bar solo for Rienzi is also cut, ${ }^{58}$ and in the act ii trio (no. 6) Adriano's two-tempo solo that closes the number was apparently suppressed. ${ }^{59}$ But many of the cuts are of large swathes of ensemble and choral writing. The act iii finale is a striking case in point where nearly 300 bars are excised (around a third of the total) in two massive cuts that involve Rienzi, Irene, Baroncelli and Cecco as well as the chorus. ${ }^{60}$ And in the act ii introduction, the chorus of ambassadors is lightly abbreviated. ${ }^{61}$

With most of the plans in place for a Parisian production, normal practice would have been for the composer to come to Paris, as had done Rossini, Bellini, Mercadante, Donizetti and Verdi. Even Weber had planned to come to supervise a production in Paris at the time of his death, and Wagner had of course participated fully in the production of Le Tannhauser in 1861. As late as January 1869 , he was still considering - or at least admitting the possibility of - coming to Paris for the production, and Judith Gautier was proposing to write an article about the composer and his arrival; but Wagner wrote to Gautier on 21 February 1869 with publication of the letter in the journal La liberté in view, and made clear that he was not going to travel to Paris for Rienzi. ${ }^{62}$ His reasons were complex:

However, my presence and my participation at the production that is in preparation could give rise to a misunderstanding. I would give the impression of placing myself at the head of an opera house with the aim of winning back through Rienzi what I had lost through Tannhäuser; it is at least thus that the press would interpret my arrival. ${ }^{63}$

Wagner's continuation of this letter is important because it is almost the only source for the background to the invitation to produce Rienzi in Paris, and in giving evidence for that story provides clues to a host of other negotiations that had been taking place during the previous year. He told Gautier of the five different plans to mount his operas in Paris, of which he 
gave the detail of three:

- A German opera troupe that would give all six of his operas in sequence in Paris

- A production of Lohengrin in Italian

- A production of Lohengrin in French

- A production of Rienzi in French

- A series of operas in French translation.

The last of these is clear from Wagner's letter to Gautier. He wrote:

When Monsieur Pasdeloup came to tell me that he had taken on the management of the Théatre-Lyrique with the intention of mounting productions of several of my works (plusieurs de mes ouvrages), I did not think I was able to refuse this zealous and capable friend the authorisation to play them, and since he wanted to begin with Rienzi, I said to him that indeed it was my opera that had always appeared to me the easiest to adapt to a French opera house. ${ }^{64}$

The latter part of this quotation shows that Wagner's view of the pedigree of Rienzi corresponds to modern received opinion, and had not changed in the ten years since he had made the same point in his 'Lettre sur la musique': ${ }^{65}$ it is a piece modelled on a French grand opéra, and shortly after Pasdeloup took over as the director of the Théatre-Lyrique on 22 August 1868 he had approached Wagner with the project of producing several of his operas, that Pasdeloup had proposed Rienzi as the first of the sequence and that Wagner had agreed.

Refusing to come to Paris did not mean that Wagner was not involved in the production of Rienzi at the Théâtre-Lyrique. Given his interest in the textual status of Rienzi at the end of the 1860s, Wagner was keen to control Pasdeloup's directorial efforts to arrange the work. He accordingly invited Pasdeloup and his stage director, Augustin Vizentini, and possibly the chorus director, Aristide Voignier, to come to Lucerne to discuss the production. Wagner's list of preoccupations is discernible from the following letter he wrote to Pasdeloup:

To be brief, I would like the contrary, that you should find the time to join me accompanied by your stage director - for a day. I want to see the designs for the sets and the costumes, then to meet, libretto in hand, the producer for all the details of the mise en scène, finally with you (I think you yourself are going to conduct the orchestra?) or with your chorus-master, to go through the score, to give my advice about tempi, and about everything there might be to convey to you from me. ${ }^{66}$

There are few surprises here: the set designs, costumes, the details of the mise en scène and 
tempi are specifically mentioned, and 'tout ce qui serait à communiquer de ma part' may well have involved the controls over the musical text - cuts and excisions - that are revealed in the surviving marked-up copy of the chorus score. When Pasdeloup finally replied to the invitation three weeks later, Wagner pressed his invitation again: 'Again and still again! Listen to me! Come for single day - since for me - to come to Paris? It's a matter with possibly - disastrous consequences for both of us. That's why I keep repeating: come and see me - and leave me in peace in Lucerne! ${ }^{67}$ The meeting took place in Lucerne on 15 March 1869, three weeks before the Rienzi premiere, and, according to Wagner's report to von Bülow, Pasdeloup made Wagner laugh a lot. ${ }^{68}$ Subsequent exchanges with his Parisian correspondents make it clear that relations between the two men extended beyond humour to a successful professional conclusion; throughout Wagner's concerns that the first run of Rienzi might be sabotaged by 'Jewish Critics' - 'les juifs des journaux', Pasdeloup always emerges not only unscathed but as a pacifying voice. ${ }^{69}$

Chief among Wagner's Parisian correspondents was Charles Truinet, otherwise known as Nuitter, and one of the librettists for Rienzi. Perhaps known today best as the archivist of the Paris Opéra for the last forty years of the nineteenth century, he is a key player in Wagner's presence in the Francophone world. Originally trained as a lawyer, and as far as can be established - continuing that career throughout his literary and theatrical life, Nuitter emerged in the early $1850 \mathrm{~s}$ as an author of vaudeville and comédie-vaudeville who quickly realised the importance of the emerging world of opérette and began a career as a librettist; he collaborated on no less than a dozen libretti for Offenbach, on libretti for opéra comique and on such well known ballets as Coppélia, ou La fille aux yeux d'émail for Delibes. His theatrical career covered the entire second half of the century, and he died in 1899. Throughout the same period, his main collaborator was Alexandre Baume, known as Beaumont. $^{70}$

In addition to this theatrical background, Nuitter's work for Wagner was grounded in many years of work as a translator, frequently in collaboration with Beaumont. The team produced the first translations into French of the three Weber operas mounted at the ThéâtreLyrique in the 1850s: Obéron, Préciosa and Abou-Hassan, and new translations - also for the Théâtre-Lyrique - of Cimarosa's Il matrimonio segreto and Mozart's Die Zauberflöte as Le mariage secret and La flute enchantée in the 1860s. They both worked with Verdi on the 1865 Paris version of Macbeth, again for the same institution. Although Nuitter was mostly associated with the Opéra as its archivist, most of his translation work was for the ThéâtreLyrique. However, his earliest involvement with the archives of the Opera was around the same time as his earliest engagement with the same institution as a translator: he worked on the French version of Bellini's I Capuleti e i Montecchi as Roméo et Juliette in 1859, and was 
the final hand in the translation of Le Tannhauser in 1861. In collaboration with Camille du Locle, Nuitter would also translate Verdi's Aida for the Opéra, together with La forza del destino and Simon Boccanegra for publication. ${ }^{71}$

Nuitter came out of the 1861 experience of Le Tannhauser bloody but unbowed, and Wagner was keen for his French collaborator to move ahead with other works. Nuitter was involved not only with translations of Tannhäuser for the Opéra and Rienzi for the ThéâtreLyrique, but he also translated Der fliegende Holländer as Le vaisseau fantôme alongside Wagner in 1861 and Lohengrin in 1868. Both were published by Flaxland, and both were later given their French-language premieres in Brussels, in 1872 and 1870 respectively.

The origins of the Rienzi translation however lay with Jules Guilliaume for a projected production in Brussels in the early 1860s that had never come to fruition, and for which Wagner prepared the score that he worked so hard to get to Paris to serve as the exemplar for Pasdeloup and Flaxland. ${ }^{72}$ Nuitter reworked Guilliaume's translation, but it is not clear exactly what that involved since Guilliaume's original has not survived; Nuitter may have reworked the poetry of both recitative and composed numbers or he may have done little more than retouch otherwise competent work. Wagner was delighted with Nuitter's 1868 Lohengrin translation to the extent that he tried to talk Schott out of using Guilliaume for the French translation of Die Meistersinger von Nürnberg in the summer of 1869, and this seems to suggest that Nuitter might have done more on the Rienzi translation rather than less. ${ }^{73}$

Pasdeloup must have been pleased with the initial impact of the production; he had already increased the size of the chorus from 70 to 120 , and the number of supernumeraries to around 200 from under half that number; the increase in size of the orchestra had meant the removal of the front four rows of seats in the stalls. ${ }^{74}$ Much of the success of the production was a direct result of expense, for which Pasdeloup would pay dearly the following year. But the response from the press to his work on the production - the soloists, chorus, orchestra, sets, costumes, ballet, mise-en-scène - was entirely positive. At the head of the soloists was Jules-Sébastien Monjauze who took the title role. ${ }^{75}$ A much-loved veteran of the ThéâtreLyrique, where he had been singing since 1855, Monjauze was praised for the way in which he negotiated what was thought to be an excess of recitative in the work. ${ }^{76}$ And he was most lauded for his performance of Rienzi's prière at the beginning of the fifth act. Savigny's description was emblematic: 'a fine beautiful aria that Monjauze sang like a great artist; since [']honour to whom honour is due['], Monjauze was the hero of the evening'. ${ }^{77}$ But for most critics it was difficult to separate the performance from the work itself. Wilfrid d'Indy's commentary was typical in this regard:

Finally, at the beginning of the fifth act, a number that we know already from the 
overture arrives to give us repose: the ravishing prayer of such generous construction, of such elevated and touching sentiment. Alas! It is too late, too late for us, whose hearing is exhausted, too late for the artist, whose voice, shaken by a four-act fortissimo, no longer has the necessary calm to rest gently on the notes, but trembles and vacillates, instead of smoothly caressing the contours of the melody. ${ }^{78}$

In general, Monjauze was also praised for his stamina and dedication to a cause that - for some critics - was of doubtful worth. ${ }^{79}$ And although Fasolla thought he was worthy of singing the role of Tannhäuser, ${ }^{80}$ ultimately any performance would be compromised in the eyes of a hostile critic. Wagner's devotees were more critical of Monjauze's performance as they alone separated his efforts from the work itself. ${ }^{81}$ Similarly, Anna Sternberg who took the role of Irène was praised, but most critics thought that she deserved a better role. ${ }^{82}$

The key point about the performance was that it was largely successful, and this opened up a discursive field for critics to reflect on the work historically, critically, aesthetically. The production cleared the ground for most of the press and other musicians to think seriously about Wagner: his writings, his personality, his career, the libretto and music of Rienzi, the future of das Kunstwerk and das Kunstwerk der Zukunft.

\section{Wagner, Wagnerians and Wagnerism}

When Wagner argued that his absence from Paris would be advantageous to the production of Rienzi, he was absolutely correct. Whether this was because he genuinely recognised that his presence might compromise his success (as he said in the letter of 21 February 1869$)^{83}$ is an open question. It may however have been - and it should be remembered that the letter to Judith Gautier was destined for publication - that he was simply so antipathetic to anything to do with Paris and France he could not bear to be there. It is also possible that it was Pasdeloup who was anxious to keep Wagner at a distance from Paris, given that he had so much more to lose than anyone else from a repeat of the 1861 Le Tannhauser debacle.

In any case, Pasdeloup was almost certainly pleased that Wagner was not in Paris, even if it did mean a journey of 700 kilometres to Lucerne and back for a single day's work. There seems to be in the environment surrounding the Rienzi premiere no attempt to capitalise on the fact that the production not only had Wagner's approval but was - to an extent - authorised by him. Such a cachet would normally have been trumpeted loudly, especially from what was effectively a secondary opera house. For example, the Opéra had mounted Rossini's Robert Bruce in 1846, at a time when Rossini was in Bologna and the librettist and music arranger, Gustave Vaëz and Louis Niedermeyer had travelled to work with Rossini - just as Pasdeloup had done with Wagner. But in 1846, the press had been full 
of accounts of Rossini's engagement, presumably fuelled by press releases from the Opéra itself. ${ }^{84}$ Pasdeloup clearly could have done the same for Rienzi, but carefully chose not to foreground Wagner's involvement in order to avoid reigniting the fire of disapproval that had burned Le Tannhauser to the ground.

Paradoxically, one of the further reasons why Wagner's absence from the Parisian Rienzi could work in favour of the production was the growth in the number of his devotees in Paris. Not only had their number been small in 1861, but Wagner had managed to alienate his Parisian supporters when he aligned himself, relatively late in the day, with the twentyfive year old Princess Pauline von Metternich, thus splitting an already small group of friends. ${ }^{85}$ But by 1869 , the private supporters of Wagner had achieved a critical mass, even if Gasperini had died the previous year, and the public supporters were equally numerous, if the accounts of their behaviour at the early performances of Rienzi are to be believed. The degree to which Wagner was supported in Paris after the debacle of the Tannhauser production can be judged by four criteria: concert performances of the composer's music, the theatrical parodies of Le Tannhauser, keyboard and other arrangements of extracts from the same work and the texts written by pro- and anti-Wagnerians. While not all of this activity stems from what might by understood by Wagnérisme, it carried the effect of the composer's work between the two theatrical productions of 1861 and 1869 .

The absence of Wagner's works in Parisian orchestral concerts until the end of the 1860 s is hardly remarkable, given the outcome of the 1861 Tannhauser production. It also however points to the fact that Wagnerians had no access to the world of concert-giving in Paris without the presence of their idol. Certainly, they could sell - or in the case of the 1860 concerts - surreptitiously buy up tickets to the concerts, but they were far from being able to mount even the most modest event. As has been seen, Pasdeloup was the sole promoter of Wagner at the Concerts Populaires. The Société des Concerts du Conservatoire were barely interested, and even Berlioz declined to programme Wagner at any of his concerts, in Paris or elsewhere. Other single performances were scattered among short-lived concert series: the Grands Concerts des Compositeurs Vivants (865), the Société de l'Athénée (1866-67) and the Société Philharmonique de Paris (1866). ${ }^{86}$

Most major productions at the Paris Opéra and Opéra-Comique were surrounded by a halo of parodies and arrangements; Le Tannhauser was no exception, bar the fact that the parodies survived better than the hypotext itself. Two works, Ya-mein-Herr and Panne aux airs - whose titles playfully parody the word Tannhauser - appeared rapidly after the work was withdrawn from the stage on 24 March 1861. Panne-aux-airs premiered at the Theatre Déjazet on 30 March, and Ya-mein-Herr at the Théâtre des Variétés on 6 April. The 52 performances that the two works enjoyed dwarfs the three performances that were accorded 
La Tannhauser. Panne-aux-airs ran until 22 April 1861 with 16 performances while Yamein-Herr was put on 36 times until 17 May 1861. Music only survives for Ya-mein-Herr, so it might be possible to advance the view that Wagner's music was given exposure even if his opera had been removed from the stage at the Paris Opéra. This was clearly not however the case, since the music for the parody (subtitled 'Cacophonie de l'avenir, en trois actes sans entracte, mêlée de chants, de harpes et de chiens savants) was taken from Félicien David's Le desert, Grétry's Richard cœur de lion, Rossini's Guillaume Tell, and works from the Variétés' more typical repertory, Les chevaliers du Pince-Nez and the Ronde du Sultan Mustafa. Only fragments of the overture and the Pilgrims march - accompanied by the chiens savants survive of Wagner's score. Although there is no evidence in the shape of any music, the surviving libretto of Panne-aux-airs suggests that Frédéric Barbier's music also made use of the Pilgrim's chorus, but also of Wolfram's romance and of Tannhäuser's act I aria. There is no doubt that the two parodies kept Le Tannhauser in the public eye for a month or so after its demise, but by the early summer of 1861 , even this was gone. ${ }^{87}$

Le Tannhauser fared rather better in the hands of its arrangers and those composers who habitually built keyboard fantasies out of the most recent operatic events. In addition to the piano-vocal score and the extracts derived from it, all prepared by the Opéra's chef $d u$ chant and Conservatoire professor, Eugène Vauthrot, and published by Flaxland, there were three or four works based on themes from the opera that were published throughout the 1860s. Both Wilhelm Krüger's transcription brillante for piano op 105 and Édouard Wolff's Grand $d u$ sur 'Tannhauser' for piano four hands were also published by Flaxland as part of the initial publicity campaign before the grim reality of the work's failure had been revealed. But Flaxland also published Giuseppe Romano's Grand duo sur Tannhauser for piano and harmonium in 1864 and Charles Neustedt's Fantaisie brillante op. 88 on themes from the work in 1868. And Liszt's Paraphrase de concert was also published by Flaxland in 1869.

A handful of piano transcriptions put on sale by the publisher does not compensate for the sort of sustained success that Gounod's Faust was enjoying during Wagner's agony with Le Tannhauser (Faust averaged 35 performances a year at the Théâtre-Lyrique until it transferred to the Opéra where it took on an even larger proportion of the repertory). The tradition of parodies, transcriptions and a few concerts was held together by a small handful of pro-Wagnerian authors who wrote in support of their favourite, often founding their own journals to do so. But even here, the outcomes were sporadic. ${ }^{88}$

The pro-Wagnerian press is centred around a few individuals. Auguste de Gasparini was surely one of the most significant, writing passionately about Tristan und Isolde in a book entitled La nouvelle Allemagne musicale, which collected together articles previously published between 1865 and 1867 in Le ménestrel, La France musicale, La presse théâtrale 
et musicale and La saison musicale. ${ }^{89}$ But when Gasparini had the chance to develop a fullyfledged Wagner criticism when he founded L'esprit nouveau with Léon Leroy in the first half of 1867, Wagner's name appeared not once, and the claims that Wagner's aesthetics lay behind Gasparini's and Leroy's journal looks very much more like wishful thinking. ${ }^{90}$ The same could not be said about Giacomelli who founded La presse théâtrale et musicale in 1860 (the journal ran until the following year. Active during the aftermath of Wagner's 1860s concerts and the Tannhauser debacle, Giacomelli, together with Edmond Roche and Robert Hyenne, were vigorous supporters of Wagner and dismissive critics of his detractors. ${ }^{91}$ The great Wagnerian, Catulle Mendès, also founded his own journal around the same time, but could only bring himself to write once about Wagner in the immediate aftermath of the withdrawal of Le Tannhauser, and his contribution pales into insignificance alongside even the Wagner criticism in the Orphéon press. ${ }^{92}$

The early performances of Rienzi were marked by some highly partisan manœuvering by Wagner's devotees, even though Théophile Gautier's report in the Journal Officiel threatened - when he compared the event to such real theatrical scandals as Hernani in 1830 - grotesque exaggeration. ${ }^{93}$ Although talk about drawing up battle lines in the opera house would be nothing more than to reinscribe Gautier's wishful thinking, the press were very quick to describe the factions in play at the premiere. They identified two groups of individuals: an extensive, well-mobilised and vociferous group of pro-Wagnerians, and the remainder of the audience who sanctimoniously disapproved of the pro-Wagnerians' uncouth behaviour - as they saw it.

There was a popular view in the press that many Wagnerians, despite their blind enthusiasm, were unaware of most of the musical and aesthetic issues that the composer's works raised. Paul Lacome - the composer - wrote a satirical analogy between Wagnerians and a fictional friend who, visiting Paris for the first time, mistook the church of Saint Sulpice for Notre Dame and then published a book about the beauties of Notre-Dame but in fact described Saint-Sulpice. Lacome's conclusion was to quote the semi-fictional Nicholas Chauvin's proverb: 'Tant moins que vous comprendrez, Tant plus qu' vous admirerez' - 'The less you understand, the more you will admire', and this of course served as a trigger for a critique of what the author thought were ill-informed Wagnerians who ignorantly trumpeted the importance of their idol. The article finished with the crypto-Adornian idea that Wagner would have needed to be defended against his devotees were it not for the fact that the composer's modesty and reticence still needed some development. ${ }^{94}$

The critic, Léon Escudier, dramatised the difference between pro- and antiWagnerian groups. In L'art musical, he wrote that: 
[The public] witnessed under arms, indifferent, calm, harmless to the locally directed enthusiasms of an entire squad of Wagnerians of good or bad faith, who had come to the opera house to applaud whatever the outcome. The Parisian public left them alone, smiling with disdain and shrugging its shoulders, without even giving itself the trouble of asking these enlisted applause-mongers if there was shame or dignity in applauding this hybrid music, this indigestible work, entirely made up of screams of the possessed and of an infernal noise. ${ }^{95}$

Escudier's general point is clear, and supported by other accounts both by those who were enthusiastic about the work and its composer as well as those who were less well disposed. But in this quotation he also pointed to two further issues: the degree to which Rienzi represented part of the project that might be described as the 'Music of the Future', and remarkably - Rienzi's 'servile imitation of certain Italian music'. ${ }^{96}$

\section{Rienzi: Aesthetic and Tradition}

Any composer venturing onto the stage of Parisian opera would have known that the background, tradition, and national style of his work would be subject to intense scrutiny, and the press responses to Rienzi - whether they were from enthusiasts or detractors - examined the work from two standpoints: from its position in Wagner's œuvre and from the perspective of its stylistic traditions.

Rienzi had been trailed long enough in the press for everyone to understand that it was a work of Wagner's youth, and in what Benoît Jouvin called his earliest style. Devotees of Die Feen and Das Liebesverbot might argue today, but such a view was conventional in 1869. Jouvin's view was a simple one, though: that Wagner had been the straightforward legatee of Weber and Marschner when he wrote Rienzi. ${ }^{97}$ And Ernest Reyer, who recognised 'a powerful, vigorous and original individuality, ... the practiced and bold hand of a composer destined to become, himself, a great master', went further. ${ }^{98}$ He claimed that it was only in his most recent works (he presumably meant Tristan und Isolde and Die Meistersinger von Nürnberg) that Wagner had escaped this tradition, and pointed to 'the heroic and chivalric breath of Euryanthe' which he thought was felt both in Rienzi and in Lohengrin. ${ }^{99}$

But the fact that Rienzi was not a recent work by Wagner - and critically that it was earlier than Tannhäuser which was the benchmark for live Parisian experience of the composer in 1869 - was used in various ways. No critics were prepared to develop Wagner's own idea that the work was a grand opéra; the only mention of grand opéra in the press was when Wagner's own words from the Quatre poèmes d'opéra were being quoted. Many critics - Reyer for example - were pleased, even relieved, that Rienzi was so different from 
Tannhäuser. Others simply pointed to the fact that, whatever success Rienzi enjoyed, it was despite rather than because of Wagner's claims to the 'music of the future'. An anonymous critic in La vie Parisienne wrote:

It appears however that this Rienzi is a work of Monsieur Wagner's youth, a timid trial, a fleeting sketch, a nothing. Thank god! It is not, it's true, that we pretend that Rienzi resembles Tannhäuser; we rather find there (astonishment!) infiltrations of the Italian style. ${ }^{100}$

The argument could, strangely, cut both ways. Paul Lacome again:

The real Wagner, the revolutionary, the ogre of Weimar, is not made this way; in a word, Lohengrin is a hundred times more melodic than Rienzi! ${ }^{101}$

This is a complex set of ideas. The frequent reference to 'pêchés de jeunesse' in the press is clearly a reference to Rossini - a figure with whom Achille-Théodore-Barthélemy LauzièresThémines, writing as Paul Gravier, clearly sympathised more than with Wagner. ${ }^{102}$ For Paris, le vrai Wagner - the true Wagner - was the Wagner of Lohengrin, even though the city had yet to hear the work. Clearly this was not the way Wagner or Wagnerians would have wanted to write history in 1869 , but for Paris this was largely the view until after the successful Paris premiere of Lohengrin itself in 1891. Lacome's reasons for making the perhaps remarkable claim that Lohengrin was a hundred times more melodic than Rienzi lay in his conviction that most of the latter was made up of

... a never-ending recitative; the old recitative, do you understand - the traditional, often interrupting its phrases with the Italian cadence on the tonic and dominant, immediately followed by the orchestra with two chords of the dominant and the tonic. $^{103}$

And in this, Lacome was pointing directly to Rienzi's stylistic antecedents, and the question of genre.

Lacome's critique of never-ending and archaic recitative harks back to debates about Gluck's recitative just as his works were falling out of the repertory in the 1820 s, to be replaced by the more dynamic approach to kinetic action found in such works as Auber's $L a$ muette de Portici, Rossini's Guillaume Tell and Meyerbeer's Robert le diable. ${ }^{104}$ It needs to be set alongside Wagner's own account of the genesis of Rienzi in the 'Lettre sur la musique' written and published in late 1860:

...Rienzi; that opera in which are found the fire, the spark that youth seeks, is the one that won me my first success in Germany, not only at the Dresden Opera House where I produced it for the first time, but since then at a large proportion of the opera 
houses where it is given alongside my other operas. This work was conceived and executed under the empire of emulation stirred in me by the youthful impressions with which the heroic operas of Spontini and the brilliant genre of the Grand Opéra at Paris had filled me, carrying the names of Auber, Meyerbeer and Halévy. ${ }^{105}$

This is well known, but Lacome's account embodies the assertion that even with the aim of emulating the work of Spontini and the masters of Parisian grand opéra, Wagner had effectively failed by first eliding the rather different styles of Spontini and the works emerging around 1830 and second by employing a style of recitative that was already outmoded.

Whether Lacome's judgement on Wagner's overuse of archaic recitative is accepted or not, there is no question that when Rienzi appeared in Paris in 1869, it was recognised both by Wagner and by critics - as a work aligned with the grand opéra with which he was so enamoured during his first stay in Paris. Although Wagner's words have assumed the status of received opinion, they may be profitably juxtaposed with an equally important thread in the fabric of Parisian Rienzi reception: that the work betrays much of the Italian. Wagner's previous opera had been Das Liebesverbot, and together with the composer's 1837 essay on Bellini, shows that Wagner had been well-disposed around 1840 to, and interested in, the assimilation of contemporary Italian opera. ${ }^{106}$ And French critics - always interested in tradition and history - were as quick to point to cavatines italiennes - 'Italian cavatinas' - as they were to the dance and marches of grand opéra or to the incipient music of the future. ${ }^{107}$ This could then be viewed either as a welcome relief from the noise of the rest of the opera or as a recognition - in the words of Charles Bannelier - that Wagner had not yet broken away from the 'old Italian errors'. ${ }^{108}$

But the juxtaposition of the Italianate and the German (whether Saxon or Prussian) was already well known to Paris, and had indeed underpinned the entire project of grand opéra. As Ernest Reyer noted:

At the time Richard Wagner wrote Rienzi, Meyerbeer had already established, and one knows with what success, a fusion between Germanic and Italian elements; the master's example so easily seduced the young composer that the latter destined his first work to our premier opera house, however ambitious a thought it was! ${ }^{109}$

According to his French critics, Wagner was imitating the Italo-German fusion of grand opéra created by Meyerbeer rather than the style forged by Halévy, Auber or even Rossini. This explains the otherwise bizarre references made in the press to Meyerbeer's Il crociato in Egitto, the last in his series of Italian operas written between 1817 and 1824, but his first work to be produced in Paris, at the Théâtre-Italien, in 1825. For Paul Gravier (Lauzières- 
Thémines), for example, Rienzi was to Tannhäuser what Il crociato in Egitto was to Les Huguenots, in other words 'a still indecisive work in which one feels that the master has not yet found his way, but where one already finds the childlike beginnings of the stuff of a seeker'. ${ }^{110}$ For Wagner's detractors, such as Léon Escudier however, Rienzi scored well below Il crociato in Egitto. ${ }^{111}$

Even those less favourable to Rienzi's appearance at the Théâtre-Lyrique recognised a shift in style throughout the work, and this corresponds exactly to what modern research on its origins has shown: that the third act onwards exhibits qualities that have been more associated with the earliest stages of work on Der fliegende Holländer which date from the same time: the early summer of 1840 . This was usually expressed in terms of a preference either on the part of the critic or supposedly on the part of the audience - for the first two acts, as suggested by Wilfrid d'Indy writing in Le correspondent. ${ }^{112}$ Overall, and notwithstanding occasional attempts by enthusiasts to claim that the work represented a successful synthesis, critical consensus pointed to a wide range of largely unassimilated styles in the work. ${ }^{113}$

\section{Das Judenthum in der Musik}

Just about every commentator on the 1869 Rienzi made comparisons between the performance and the reactions to the production of Tannhaüser eight years previously. Not only did the Rienzi production run to 38 performances, but there were none of the difficulties that Wagner had encountered earlier. There were however some similarities. For example, Wagner's prose texts were much under discussion in the approach to both productions. In the case of Tannhäuser, it was Oper und Drama and the 'Lettre sur la musique'; for Rienzi, things might have thought to be more tense since the text that was under scrutiny in 1869 was Das Judenthum in der Musik. ${ }^{114}$

On both sides of the critical divide, authors enthusiastically condemned and complimented Rienzi, but did so in a way that was radically different to the diatribes surrounding the 1861 Le Tannhauser. The even-handedness surrounding the 1869 Rienzi is in large part one of the reasons this series of cultural events is so valuable in advancing an understanding of Wagner in Paris before the silence after 1870. But one of the overriding concerns in the reception of Rienzi in Paris in 1869 was the set of issues arising out of Wagner's Das Judenthum in der Musik, translated into French variously as Les juifs musiciens or Le judaïsme dans la musique. ${ }^{115}$ The response to Das Judenthum in France is best considered alongside the aggressively pro-Wagnerian pamphleteering during the 1860s. While most pro-Wagnerian writing in Paris was conceived ab initio by its authors rather than in response to events, and could appear at any time, anti-Wagnerian writing in the 1860 s was 
triggered firstly by the two major productions on the stage (Le Tannhauser in 1861; Rienzi in 1869) and secondly by responses in turn to pro-Wagnerian commentaries when they trespassed onto arguments ad hominem, or were reviews of such publications as the Quatre poèmes d'opéra in 1860 (much overshadowed by the preceding 'Lettre sur la musique') or the 1863 summary of the libretto of Der Ring des Nibelungen. ${ }^{116}$

A good example of pro-Wagnerian polemics was Léon Leroy's handling of the 1865 premiere of Tristan und Isolde in Munich. He wrote to the editor of a journal called Le nain jaune, Aurélien Scholl, publicly asking if the latter would like a review of the Tristan premiere, and describing the forthcoming event as something as enormous as the Austrians' crossing of the River Mincio during the Second Italian War of Independence or of the entry of the French fleet into the Dardanelles before the Crimean War. ${ }^{117}$ With such a preview, Scholl could hardly refuse, but to read Leroy's subsequent review is almost to witness the latter's disappointment, since - according to him - Wagner's implacable enemies were routed at the performance by the applause of the 1800 members of the audience. ${ }^{118}$ This fits ill with other accounts of the Tristan premiere but is a good indication of the ways in which proWagnerians could keep the composer's presence in the eyes, minds, and - to a degree - ears of their Parisian contemporaries, by stressing the contentious and controversial nature of the composer's activities, even if they would then backtrack in favour of mere panegyric.

And this is the background into which Wagner's own texts should be assimilated. Although the key text that had underpinned the 1861 Le Tannhauser production was the summary of Oper und Drama that appears in the 1860 'Lettre sur la musique', and although Das Judenthum in der Musik had been translated into French and published twice in Belgium and in La France musicale in Paris before 1861, it made no impact whatsoever, and was not mentioned in the tens of thousands of words published about the 1861 Le Tannhauser. The 1869 Rienzi was totally different. Just before the April premiere, the revised text of Das Judenthum had been published with Wagner's new Aufklärungen über 'Das Judenthum in der Musik' and the earlier French translation had been republished in pamphlet form in Brussels. ${ }^{119}$ It dominated the response to Rienzi, but not in the way it might be expected to today. For there is not a jot of censure in the commentaries on Das Judenthum in the French press of Wagner's unbridled anti-Semitism. What are found are two related responses: the first a rather tired acknowledgement of Wagner's recurring paranoia that the failure of his works across Europe were the product of a Jewish conspiracy, and the second universal outrage at his slander of the much revered and only recently deceased Meyerbeer. For the first, a scathing sample from the journal L'illustration was penned by an author known only by his surname, Savigny: 
Wagner, who fills Germany with the noise of his name and the auditorium of the Théâtre-Lyrique with the racket of his music, thinks that he is pursued by the Jews; it is Judas' plot against him; he declaims it, he proclaims it; this role of the martyr is so essential to success. Why do all of that, and why do we need to know it? ${ }^{120}$ Hippolyte Prévost spoke for pretty well the entire critical world when he quoted large passages from the French translation of Das Judenthum and followed it with his own commentary:

Here is how Wagner appreciates the sublime compositions of a man of genius that the universe has recognised with its acclamations, whose death has indeed increased his renown. Thus, Les Huguenots, this masterpiece of the human spirit in music whose every note is engraved on bronze with a diamond point is worthless, as is Guillaume Tell, in the eyes of this madman, of this monomaniac, of this new Herostratus, of this fanatical destroyer: he tries to set fire to the temple of taste, in the sanctuary of which he has not yet placed a single stage work, having tried in vain to shake its columns of marble and granite. ${ }^{121}$

Less than generous, it might be said, but this is one of the more measured responses to Wagner's attacks on Meyerbeer. Some authors - Albert Wolff and Rémy Fasolla - dedicated entire articles to Wagner's comments on Meyerbeer in Das Judenthum or disguised them in a purported review of Rienzi. ${ }^{122}$

The implications of the French response to Das Judenthum belong to a much wider story, but in summary the effect of the very particular reception of Das Judenthum, coupled to a strong showing on the part of the Wagnerians themselves at the Théâtre-Lyrique, meant that the production of Rienzi would continue until Pasdeloup's bankruptcy in January 1870; it ran until the end of the 1868-69 season, opened the 1869-70 season, and in an act of bravado was Pasdeloup's last performance at the Théatre-Lyrique in 1870. But there is another reason for the success of Rienzi in Paris as the Second Empire staggered towards its catastrophic end at Sedan in September 1870, and that is its relationship with events on the European stage, and the skilful way in which Pasdeloup negotiated them on behalf of his opera house.

\section{Wagner and European Foreign Policy, 1866-1871}

In its uncompromising juxtaposition of the leading exponent on German-language music for the theatre with the musical capital of the nineteenth century, Rienzi invited an artistic review of European diplomatic relations of the previous half decade involving the Austrian Empire, Prussia, Bavaria, and France. 
Given the nature of Rienzi's plot, and the luxurious staging given by the ThéâtreLyrique, it is hardly surprising that military imagery was common in press accounts of the premiere. Gustave Chadeuil was just one among many when he wrote that 'On the podium, Monsieur Pasdeloup was installed like a Field Marshall who is about to start a battle on which the whole future could depend. His reinforced army was held in readiness, with reserves ready backstage, cannons aimed and swords drawn'. ${ }^{123}$ Military imagery had been popular to describe many of Wagner's premieres - Champfleury's Après la bataille and Leroy's minatory preview of the Munich Tristan premiere have already been mentioned. Such imagery could verge on the commonplace, however, and did not only describe the contentious and the controversial; here is a premiere from 1836: 'And how could it have been otherwise? How could this great and memorable battle not have ended with the most vivid of victories when, under the direction of an experienced and conscientious conductor, all that the grande armée of the Opéra considered experienced soldiers were fighting, and with what devotion, what enthusiasm!'. ${ }^{124}$ This is no bloody battlefield from which the corpse of an unsuccessful opera is dragged, but the 1836 premiere of Meyerbeer's Les Huguenots, one of the most successful premieres in nineteenth-century Europe. But the concentration and density of military imagery in the commentary on Rienzi was truly remarkable, and the presence in Paris of a work by a Saxon composer -Wagner - who had publicly insulted a Prussian one Meyerbeer - and who was patronised by a Bavarian -Ludwig II - dramatised on the boards of a French opera house the main protagonists in European diplomacy of the previous five years.

It is a short step from this sort of military imagery to the presentation of elements of European diplomacy as a proxy for criticism of Wagner's Rienzi. There are three related phases of French foreign policy in the second half of the 1860s that impinge on the 1869 Rienzi production. France was only involved in the last, but it is widely acknowledged that all these events were key to France's place in Europe in the second half of the 1860s. They are the Austro-Prussian War of 1866, the Spanish Revolution of 1868 and the FrancoPrussian War of 1870.

The outcome of the Austro-Prussian War of 1866 was a shock for the French, and the unexpected but comprehensive defeat of the Austrians by Prussia at the Battle of Königgrätz on 3 July 1866 made clear that Prussia was a real danger to France's position in Europe. The Austrians' desire for revenge for their defeat at Königgrätz - or Sadowa, as it was often called - was shared by the French. In his description of the Théâtre-Lyrique, Chadeuil lightly modified history when he explicitly identified the 1861 Le Tannhauser as Königgrätz and the 1869 Rienzi as Wagner's revenge for defeat: 'Finally, we're going to take a brilliant revenge: after Tannhäuser we shall have Rienzi, to erase the Sadowa of Monsieur Wagner'. ${ }^{125}$ The two Parisian Wagner productions from the beginning and end of the 1860 s are explicitly linked to 
events on the European stage in ways clearly designed to encourage reflection on the parallels not only between Le Tannhauser and Rienzi but between Rienzi and the unfolding darkness overshadowing Europe.

Little known in France was the role that Wagner played in Ludwig II's deliberations up to and including the war of 1866; this was important, because although Bavaria was ostensibly an ally of Austria against the Prussians, Bismarck's attempts to convince Ludwig II to remain neutral resulted in at best a half-hearted Bavarian involvement that largely contributed to Austria's defeat and humiliation. At the very least, Wagner was the object of Bismarck's attentions as he tried to interfere with Ludwig's foreign policy during the early summer of 1866. Bismarck's attempts to influence Ludwig II's involvement in the AustroPrussian War were made particularly difficult by the pro-Austrian stance of Ludwig Karl Heinrich Freiherr von der Pfordten and the Bavarian government. Bismarck endeavoured to circumvent this opposition vicariously through two routes direct to the twenty-year-old monarch. First, he approached the king through the pro-Prussian Chodwig zu HohenloheSchillingfürst; second, he attempted to influence the King via François Wille - a student friend of Bismarck and now a friend of Wagner. ${ }^{126}$ The latter's letters to Ludwig II in June of 1866 constantly project a pro-Prussian stance to the extent of recommending Hohenlohe as prime minister to replace Pfordten, a move that eventually took place in December $1866 .{ }^{127}$ Whether Wagner was genuinely interested in trying to help Ludwig II develop Bavaria as a buffer state between Austria and Prussia or whether he thought that any antagonist to France was worthy of support is difficult to establish, especially in the light of Bavaria's rapid reversal of opinion concerning Prussia at the end of the Austro-Prussian War. Wagner's proximity to Bismarck did not escape some French journalists, one of whom - Jules Guillemot - reckoned that it was easy to confuse Wagner and Bismarck physically, at exactly the time of the Rienzi premiere in April 1869: 'Show this portrait [of Wagner] to someone to whom the features of contemporary celebrities are unknown, tell him that it represents one of the men who has most shaken up Germany in recent years, and it is a good bet that he will name Monsieur de Bismarck before thinking of Wagner'. ${ }^{128}$ And d'Indy described the complexity of the libretto of Rienzi and explicitly connected it to the machinations of Bismarck's foreign policy. ${ }^{129}$

The succession to Isabella II of Spain after the revolutionary Battle of Alcolea on 27 September 1868 and her exile in Paris were central to French politics during the preparations for, and early performances of, Rienzi. The reason was the so-called 'Hohenzollern Candidacy'. ${ }^{130}$ Whoever ruled Spain would be a key ally either for France or Prussia - the two major powers after the Austro-Prussian War, and both had candidates: Antoine d'Orléans, Duc de Montpensier for the French and Leopold von Hohenzollern-Sigmaringen for the 
Prussians. ${ }^{131}$ The Duc de Montpensier was unacceptable largely because he was the brotherin-law of the recently deposed Isabella II. Leopold von Hohenzollern was recognised as a credible candidate and therefore a threat to France in the French press as early as November 1868; the 'Hohenzollern Candidacy' and would continue as a German presence in French domestic and overseas policy for the next eighteen months as much as would Wagner's Rienzi in French cultural and artistic politics. ${ }^{132}$ Both would form part of the background to the worsening relationship between Prussia and France, the fiasco of the so-called 'Ems Dispatch' and the Franco-Prussian War itself. In short, as the subscriber read her copy of the Journal des débats over 'the dainty croissant on the boudoir table', ${ }^{133}$ the crumbs would fall alternately on accounts of the preparations and early performances of Rienzi and on descriptions of the not-so-veiled Prussian threats to French hegemony via the Hohenzollern claims to the Spanish crown.

Wagner's presence simultaneously in both Franco-European diplomacy and at the centre of Parisian operatic culture invites a re-reading of aspects of Rienzi in the light of geopolitics at the end of the 1860s. In general, the rise and fall of a leader - from saviour to tyrant in five acts - well reflects the astonishing change in fortunes of the French state in five years. Furthermore, the libretto of Rienzi has moments - that were often subtly re-interpreted for the 1869 production - where a parallels with contemporary events might well have given audiences pause for thought. Two passages are instructive.

The relationship between the French state and the Papacy was a principal driver for the actions of Rienzi's censors. ${ }^{134}$ In the libretto of Rienzi, the diplomatic position of the Pope is key, and nowhere more so than at the sombre $\mathrm{C}^{\#}$ minor opening of the fourth act. Here, Rienzi's supporters, Baroncelli and Cecco, surrounded by a chorus of bourgeois citizens, lament the cost to the city of armed struggle. But Cecco has more to report than merely 'la crainte et la tristesse': Germany (l'Allemagne) has forsaken Rienzi and entered into a pact with the Papacy. ${ }^{135}$ Furthermore, the position is worsened by the enemy Colonna's alliance with the Pope:

Colonna, quand il s'est enfui,

When Colonna fled,

A fait, dit-on, un pacte avec l'Église, He made, it is said, a pact with the Church, Et du Saint-Père c'est l'appui And it is the support of the Holy Father

Qui secondait son entreprise That advances his endeavours. ${ }^{136}$ In such a context, the fourteenth-century alliance of the Pope with 'Germany' could be read as a nineteenth-century agreement with Prussia, Bavaria or even the Austro-Hungarian Empire. And under such circumstances it would be difficult to see the embattled Rienzi and 
Rome as anything other than Napoleon III and France, while alliances on the far side of the Rhine began to solidify.

When Wagner embedded a multi-section divertissement in his opera, he prefaced it with a series of greetings from ambassadors representing Milan, Lombardy, Naples, Bohemia and Bavaria. Before the ballet, each ambassador greets Rienzi and the city of Rome on behalf of his head of state. This is carefully worked out so that each is scored slightly differently as follows (table 2): ${ }^{137}$

\section{Table 2}

Each state is differentiated by a different vocal scoring within the context of a single movement that begins and ends in E major with central passages in G major. The 1869 revision of this scene replaces the ambassadors in ways that bring the work immediately up to date: Milan and Lombardy are simply aggregated into the 'États Lombards', Naples remains, as do Bavaria and Bohemia, but Hungary is added to the list. This list, given in the printed libretto, is entirely missing in the censors' copy, where the names are replaced by 'les députations des différentes provinces'. ${ }^{138}$ But the list in the printed libretto, in separating out Hungary, clearly responds to the so-called Austrian-Hungarian Compromise of 1867 where Hungary was permitted - in small part - to secede from the Austrian Empire in the wake of the Austrian defeat by Prussia in the Austro-Prussian war the previous year. Exactly where this inflammatory list came from - and it seems to have emerged after the libretto was reviewed by the censor in the last week of December 1868 - is unclear. Given Pasdeloup's contact with Wagner in March and April 1869, it is not impossible that Wagner himself could have engineered this inclusion. Given Hungary's key role in ensuring that Austria did not side with Prussia in the years approaching the Franco-Prussian War, its inclusion in the 1869 Rienzi might be viewed as analogous with Wagner's pressure on Ludwig II to keep Bavaria neutral in the same conflict.

Musically speaking, the changes to the ambassadors created two types of difficulties: the use of the two basses originally destined for the messengers from Bohemia and Bavaria worked ill for the single ambassador from Hungary and, more generally, there was a question of just how great an emphasis should be given to this musico-political statement. The solution looks very much like a plan concocted by Wagner but mitigated in Paris by Pasdeloup since although the passage is exactly the same length in the 1869 version the vocal sections of this scene are entirely suppressed: the scene effectively becomes a procession and, as popular relatively recently, placed just before the ballet. ${ }^{139}$ Thus, the updated political participants in the scene are present but they are denied their individual musical utterances. This attempt to vitiate the incendiary changes to the libretto is entirely congruent with 
Pasdeloup's attempts to downplay Wagner's involvement in the production in order to avoid the sorts of difficulties that had plagued the 1861 Le Tannhauser.

There should be no attempt to argue that the 1869 Rienzi directly embodies political resonances of the late 1860 s, and certainly no claim that there are any correspondences to be drawn between specific events in the libretto and in contemporary diplomacy. However, it is difficult to imagine that the parallels described here would have gone unnoticed by an audience as well versed in current affairs as in the appreciation of opera. The invocation of key European allies and enemies would have been not only familiar to all but visible within the pages of the same newspapers that described the preparations for the Théâtre-Lyrique's Rienzi. The success of Pasdeloup's attempts at minimising any deleterious effect of such observations on the production is witnessed by the fact that most comments of this sort in the press were not used as a reason for negative criticism of the work or its production.

The French reception of Wagner is often viewed through the murky lenses of the two productions of Tannhäuser in 1861 of Lohengrin in 1891. Sufficient is now known about the composer's earliest attempt to engage with Parisian music drama around 1840 to be able to understand his earlier work on Das Liebesverbot, Rienzi, Der fliegende Holländer, and his emerging relationship with key figures in Parisian musical life, Meyerbeer most notably. A clearer picture is also beginning to emerge of Wagner's place in French cultural life and letters in the 1850 s.

Wagner's position in Paris during the 1860s, culminating in the production of Rienzi at the Théâtre-Lyrique in 1869 , is complex and multifaceted. There were no staged versions of his operas between 1861 and 1869, and the very existence of a successful Parisian premiere for an opera by Wagner in 1869 - given that there would be almost nothing for two decades after 1870 - is remarkable in itself. The 1860s furthermore saw the emergence of a coherent voice of Wagnerism, the presence of French Wagnerians at the composer's premieres all over Europe and a developing discourse in French around them. This may be set against a continuing tradition of performing extracts of Wagner's operas throughout the $1860 \mathrm{~s}$, largely through the energies of Jules Pasdeloup, who as director of the Théâtre-Lyrique was also responsible for the 1869 Rienzi. This production - so little known up till now - provides not only a stable musical basis on which to assess the status of Wagner on the eve of the FrancoPrussian War, with none of the histrionics associated with the 1861 Le Tannhauser fiasco. It also provides a compelling parallel with Wagner's own political machinations at the court of Ludwig II that were carefully resisted or disguised by Pasdeloup. As a more comprehensive 
picture of Wagner's works in the cultural transfer of stage music in Europe in the second half of the nineteenth century is developed, the 1869 production of Rienzi assumes a key role. 
*Parts of this article were presented at the School of Advanced Study, University of London, May 2012; University of Queensland, September 2012; as a keynote address at the Royal Musical Association Research Students Conference, Southampton, January 2013; Columbia University, April 2013; University of Chicago April 2013. I am grateful to Jeremy Coleman, Thomas Grey, Willliam Weber and Kimberly White for reading and commenting on drafts of the text.

${ }^{1}$ Current understandings of Wagner in France are based on a wide range of distinguished works. Georges Servières, Richard Wagner jugé en France (Paris: Librairie Illustrée, 1898) is still valuable for its discussion of printed material (both periodical and monograph sources). Thomas Grey, 'Richard Wagner and the Legacy of French Grand Opera', The Cambridge Companion to Grand Opera, ed. David Charlton (Cambridge: Cambridge University Press, 2003), 321-343, contextualises the entire Wagner canon within the domains of Parisian grand opéra. Also useful is Martine Kahane and Nicole Wild, Wagner et la France [Exhibition Catalogue, Théâtre national de l'Opéra, Paris, 26 October - 26 January 1984 (Paris:

Bibliothèque Nationale; Théâtre National de l'Opéra de Paris; Herscher, 1984). Gerald D. Turbow, 'Art and Politics: Wagnerism in France', Wagnerism in European Culture and Politics, ed. David C. Large and William Weber (Ithaca and London: Cornell University Press, 1984) 134-166 and 323-330; and the wide ranging collection of essays in Von Wagner zum Wagnérisme: Musik, Literatur, Kunst, Politik, ed. Annegret Fauser and Manuela Schwartz, Deutsch-Französiche Kulturbibliothek 12 (Leipzig: Leipziger Universitätsverlag, 1999) are fundamental. Such works as Maxime Leroy, Les premiers amis français de Wagner (Paris: Albin Michel, 1925) are best considered as a continuation of Wagnerism itself rather than as critical accounts of the subject. The articles 'WAGNER, Richard' and 'wagnérisme' in Joël-Marie Fauquet, ed., Dictionnaire de la musique en France au xix siècle (Paris: Fayard, 2003), 1298-1299 and 1306-1307 are relatively up-to-date introductions, although it should be noted that the table 'Premières exécutions et représentations publiques des œuvres de Wagner in France avant 1900', ibidem, 1303-1305, inexplicably omits the years 1891 and 1892 and the earliest performances of Lohengrin in France.

${ }^{2}$ This is not uniquely typical of Wagner. Juxtaposing the scholarship on the Parisian reception of not only Wagner, but also of Verdi, Bellini, Donizetti, Mercadante and even Spontini with that on Auber, Halévy, Adam - Gounod even, simply shows how much more attention composers with a reputation that survives into the twenty-first century receive in scholarly accounts of their works. 
${ }^{3}$ For an account of these earliest engagements see Katharine Ellis, 'Wagnerism and AntiWagnerism in the Paris Periodical Press, 1852-1870', Von Wagner zum Wagnérisme, 51-70. See also Sabine Le Hir, 'Wagner et la France (1830-1861): nouvelle approache des relations de Wagner avec la France à la lumière de son raport à l'Allemagne et de la réception française de son œuvre' (PhD diss., Université François-Rabelais de Tours, 2016), which however stops short of the 1861 Le Tannhauser fiasco.

${ }^{4}$ Emmanuel Chabrier, Le roi malgré lui (1887), Bruneau, L'attaque du moulin, Augusta Holmès, La montagne noir (1895), Vincent d'Indy, Fervaal (1897), Gustave Charpentier's Louise (1900, Claude Debussy, Pelléas et Mélisande (1902), Ernest Chausson, Le roi Arthus (1903) have taken on a canonic status of their own at least in part as a result of their Wagnerian credentials, and have received the sort of attention of which their non-Wagnerian contemporaries could only dream. See the full account in Steven Huebner, French Opera at the Fin de Siècle: Wagnerism, Nationalism and Style (Oxford: Oxford University Press, 1999), which sets the above works in context alongside non-Wagnerians and what Huebner (ibidem, 169-234) elegantly calls 'ambivalent Wagnerians'.

${ }^{5}$ For the text of the 1861 Le Tannhauser, see Reinhard Strohm, Peter Jost, and Cristina Urchueguia, eds, Richard Wagner: Tannhäuser und der Sängerkrieg auf Wartburg, 7 vols, Sämtliche Werke 3 (Mainz, etc.: Schott, 1980-2003); Caroline Abbate, 'The 'Parisian' Tannhäuser', (PhD diss., Princeton University, 1984); eadem, 'The Parisian 'Venus' and the 'Paris' Tannhäuser', Journal of the American Musicological Society 36 (1983) 73-123. Georges Servières' Tannhaeuser à l'Opéra en 1861 (Paris: Fischbacher, 1895) is a reprint of a chapter from his Richard Wagner jugé en France aimed at the 1895 Paris revival of the work. For the 1891 Lohengrin, see Manuela Schwartz, 'La question de Lohengrin: die politischen und kulturellen Hintergründe der Lohengrin-Aufführungen zwischen 1869 und 1891', Von Wagner zum Wagnérisme: Musik, Literatur, Kunst, Politik, ed. Annegret Fauser and Manuela Schwartz, Deutsch-Französiche Kulturbibliothek 12 (Leipzig: Leipziger Universitätsverlag, 1999) 107-136; Ellis, 'How to Make Wagner Normal: Lohengrin's Tour de France of 1891-92', Cambridge Opera Journal 25 (2013), 121-137; and Yannick Simon, 'Lohengrin': un tour de France, 1887-1891 (Rennes: Presses universitaires de l'université Rennes 2, 2015).

${ }^{6}$ Exceptions are Servières, Richard Wagner jugé en France, 115-172, which is based largely on the contemporary press and Andreas Mielke, ed., Briefe des Jahres 1869, Richard Wagner: Sämtliche Briefe 21 (Wiesbaden, Leipzig and Paris: Breitkopf \& Härtel, 2011), 392-404, which is based on Wagner's correspondence supplemented by those press reports included by 
Servières. I thank Andreas Mielke of the Richard-Wagner-Briefausgabe for sharing with me the edition of volumes 20-22 of the edition in advance of publication.

${ }^{7}$ In addition to the studies of the text of Le Tannhauser itself, many have sought to understand the reasons for the failure of the work in Paris. In many respects the subject is rendered problematic by the lengthy and one-sided account in Mein Leben; see Richard Wagner, Mein Leben: Erste authentische Veröffentlichung, ed. Martin Gregor-Dellin (Munich: List, 1963), trans. Andrew Grey and ed. Mary Whittall as My Life (Cambridge: Cambridge University Press, 1983) 592-643 (page numbers refer to the 1983 English translation). Further, see Kelly Jo Maynard, 'The Enemy Within: Encountering Wagner in Early Third Republic France' (PhD diss., University of California at Los Angeles, 2007), 2634; Robert Giesburg, 'Wagner and France', Wagner in Retrospect: A Centennial Reappraisal, ed. Leroy R. Shaw, Nancy R. Cirillo and Marion S. Miller (Amsterdam: Rodopi, 1987), 106116; Imre Ormay, Skandal in der Oper, trans. István Frommer (Budapest: Corvina Deutscher Verlag für Musik, 1967), 98-146; Ulrich Drüner, 'La version parisienne du Tannhaüser de Richard Wagner, ou L'introduction du psychologique dans le grand opéra', Le Théâtre lyrique en France au xix ${ }^{e}$ siècle, ed. Paul Prévost (Metz: Éditions Serpenoise, 1995), 163-180; Turbow, 'Art and Politics'; Léon Guichard, La musique et les lettres en France au temps du wagnérisme (Paris: Presses universitaires de France, 1963). Paul Lindau, 'Die Geschichte von Richard Wagners Tannhäuser in Paris: ein Brief', in his Dramaturgische Blätter: Beiträge zur Kenntniss des modernen Theaters in Deutschland und Frankreich, 2 vols (Stuttgart: Simon, 1874) 2:221-247 claims first-hand authority for his commentary.

${ }^{8}$ Carl Dahlhaus' view of the subject is emblematic. He recruits Charles Gounod as a witness for the prosecution in his show-trial of Parisian operatic culture when he writes: 'The apparent miscarriage of Tannhäuser in 1861 was, as Gounod recognized with the shrewd eye of a colleague, in reality a triumph' (Nineteenth-Century Music, tr. J. Bradford Robinson (Berkeley, Los Angeles and London: University of California Press, 1989), 285). The passage is fraught with difficulties. The English translation 'miscarriage' barely does justice to the word Niederlage (which has the sense more of a defeat or rout; German terms for miscarriage centre on such terms as 'Fehlschlag' or 'Mißlingen' [childbirth] or 'Fehlspruch' or 'Justizirrtum' [miscarriage of justice]). But this is nothing compared to Gounod's original text, which reads: 'Vous appelez cela une chute; j'appelle cela une émeute' (Georgina Weldon, ed., Autobiographie de Ch. Gounod et articles sur la routine en matière d'art (London: author, 1875), 18 (emphasis added)): the words 'chute' and 'émeute' juxtapose 'failure' and 'riot', which makes complete sense of Gounod's quip, especially in the context 
in which it is originally set. Dahlhaus' haste to defend Wagner and the former's translation of 'émeute' as 'Triumph' - and then 'triumph' in English - and therefore his rewriting the history of the failure of the 1861 Le Tannhauser largely reverses the sense of Gounod's original commentary. See the original German text in Carl Dahlhaus, Die Musik des 19. Jahrhunderts, Carl Dahlhaus: Gesammelte Schriften 5 (Laaber: Laaber, 2003), 279.

Strangely, there is a much better-known quotation from Gounod about the Le Tannhauser fiasco, in Mein Leben (639) where the latter is reputed to have said 'Let God give me such a failure!' ('Que Dieu me donne une pareille chûte!').

${ }^{9}$ Robert Wangermée's article on Fétis (Robert Wangermée, et al. 'Fétis', Grove Music Online. Oxford Music Online. Oxford University Press, consulted 11December, 2013, http://www.oxfordmusiconline.com/subscriber/article/grove/music/09564pg1) is an excellent introduction, that may be read with profit alongside the essays in François-Joseph Fétis (1784-1871), ed. Marie Cornaz, Varlérie Dufour and Henri Vanhulst, special issue of Revue belge de musicologie 62 (2006). Paul Scudo has not fared so well. The brief article by Jeffrey Cooper (Jeffrey Cooper. 'Scudo, P.', Grove Music Online. Oxford Music Online, Oxford University Press, consulted 11 December, 2013, http://www.oxfordmusiconline.com/subscriber/article/grove/music/25273) compares unfavourably with the article in François-Joseph Fétis, Biographie universelle des musiciens et bibliographie générale de la musique, 8 vols (2nd edn. [with supplement in two vols] Paris: Firmin Didot, 1860-1865) 7:546-548. Relevant to the current inquiry is Rémy Campos, 'Paul Scudo contre Richard Wagner: Autopsie d'une oreille réactionnaire' The Legacy of Richard Wagner: Convergences and dissonances in aesthetics and reception, ed. Luca Sala, Speculum musicae 18 (Turnhout: Brepols, 2012), 53-76.

${ }^{10}$ Fétis' articles in the supplement to his Biographie universelle are the only guides to the careers of both Gasparini and Giacomelli. The latter (ibidem, suppl. 1:377 was given a slightingly terse account whereas Fétis recognised a real literary gift with Gasparini (ibidem, supp. 1:365).

${ }^{11}$ Baudelaire's 1861 essay - and to a lesser degree Champfleury's Après la bataille - have received a disproportionate level of attention in recent discussions of the production of $L e$ Tannhauser in comparison with their contemporary impact or to the quality of commentary contained within. It is difficult to imagine that the text that was finally titled 'Richard Wagner et Tannhaüser [sic] à Paris' would have had the same effect if its author were not the notorious author of Les fleurs du mal. Closer readings of Baudelaire's text, however, show that it was largely a description not of Le Tannhauser of 1861 but of Wagner's concerts that 
had preceded it. The account of the premiere of Le Tannhauser is an appendix to the Dentu edition of the text. The Baudelaire has been translated into English, Italian, German, Serbian, and Hungarian whereas most of the rest of the voluminous criticism of Le Tannhauser has until recently been completely neglected. This is all the more striking since it has been argued that Baudelaire's essay was in fact based on a much earlier text, 'Du vin et du hashisch' which first appeared in Le messager de l'Assemblée, 3 July 1851, and was subsequently published in a much revised form in 1860 as part of the collection Paradis artificiels. See Michèle Finck, 'Portrait de Baudelaire en guitariste espagnol: Lecture d'une page des Paradis artificiels', Les cahiers du RITM: Centre de recherches interdisciplinaires sur les textes modernes de l'Université Paris X 21 (2000), 55-74. The published version of the revision of 'Du vin et du hashisch' as 'Richard Wagner et Tannhaüser [sic] à Paris' is in the Revue européenne, 4 May 1861, and reprinted as Charles Baudelaire, Richard Wagner et Tannhaüser [sic] à Paris (Paris: Dentu, 1861). Such a genealogy of the text has not stifled a reading of Baudelaire's text in the context of Wagner reception: see Susan Zeldes Bernstein, 'Virtuosity of the nineteenth century: Music and Language in Heine, Liszt, and Baudelaire' (PhD diss., Johns Hopkins University, 1991); Noel Verzosa, 'Wagner Reception and French Modernity before and after Baudelaire: The Case of the Revue wagnérienne', Music Research Forum 22 (2007), 1-33, where Baudelaire is elevated to a key point of change in Wagner reception; Etienne Barlier, 'La musique du sublime', Wagner: Lohengrin, L'avant-scene opéra 143-144 (Paris: L'avant-scène opéra, 1992), 159-163; Margaret Miner, 'Putting the Emphasis on Music: Baudelaire and the Lohengrin Prelude', Nineteenth-Century French Studies, 21 (1993) 384-401; eadem, Resonant Gaps: Between Baudelaire and Wagner (Athens GA: University of Georgia Press, 1995); Candace Kirsten Skorupa, 'Music and Letters: Correspondences of Notes and Narrative from Berlioz to Proust' (PhD diss., Yale University, 2000) where Baudelaire is privileged as an early example of musically-inspired literature at the expense, for example, of E.T.A. Hoffmann or Balzac; most remarkably a study of brain functions in music based on Baudelaire and his Wagner text: Bernard Lechevalier, Le cerveau mélomane de Baudelaire: musique et neuropsychologie (Paris: Jacob, 2010); Johannes Schütze, 'Richard Wagner in Paris-Baudelaire und Wagner', Bremen und die Niederlande, special issue of Jahrbuch der Wittheit zu Bremen 19 (1975) 69-90; Marina Vallorami, 'Baudelaire, Lohengrin, Tannhäuser: reflessioni sugli effetti wagneriani' Nuova rivista musicale italiana 23 (1989) 541-546. An attempt at redressing the balance by publishing the entire range of press criticism from the 1861 Le Tannhauser is the digital edition of the press commentary on the 1861, Le Tannhauser, in William Gibbons and Annegret Fauser, 'Le Tannhauser in Paris, 1861', Francophone Music Criticism Collection 5, 
http://music.sas.ac.uk/fmc (consulted 10 December 2013). See, for studies of the press response to Le Tannhauser, Katherine Kolb, 'Flying leaves: Between Berlioz and Wagner', $19^{\text {th }}$-Century Music 33 (2009), 25-61; Jean-François Candoni, 'Richard Wagner: Texte, musique et drame', Études germaniques 3 (1999) 415-439; Annegret Fauser, 'Cette musique sans tradition: Tannhäuser and its French Critics', Music, Theater and Cultural Transfer: Paris, 1830-1914, ed. Mark Everist and Annegret Fauser (Chicago: Chicago University Press, 2009), 228-255. See also eadem, 'Debacle at the Paris Opéra; Tannhäuser and its Critics, 1861', Richard Wagner and His World, ed. Thomas S. Grey (Princeton NJ: Princeton University Press, 2009), 347-350.

${ }^{12}$ Léon Leroy figures hardly at all in the literature whereas Schuré has recently been the subject of Eryck de Rubercy, 'Édouard Schuré: le renversement de tendance', La controverse Wagner: Tannhaüser [sic] à Paris en 1861, Agora: Presses Pocket [Revue des deux mondes] (Paris: Lattès, 2012) 67-95. Judith Gautier (she styled herself Mendès between 1866 and 1874 when she was married to Catulle Mendès) has been the subject of two monographs: Joanna Richardson, Judith Gautier: A Biography (London and New York: Quarter, 1986) which did not really supplant Mathilde Camacho, Judith Gautier: sa vie et son ouvre (Paris: Droz, 1939).

${ }^{13}$ Catulle Mendès' support for Wagner was unwavering despite the latter's authorship of the satirical Ein Kapitulation in 1871, which triggered a personal break. But Mendès wrote very little about the composer in the 1860s, even the Revue fantaisiste (which ran only during 1861) carried very little of the editor's own work. Most of Mendès' writing about Wagner dates from after 1870

${ }^{14}$ The outlines of the Wagnerian concert tradition in Paris are given in Fauquet, 'Premières exécutions', 1303.

${ }^{15}$ See Thomas Joseph Walsh, Second Empire Opera: The Théâtre Lyrique, Paris, 1851-1870, The History of Opera (London: Calder; New York: Riverrun, 1981), 241-275.

${ }^{16}$ For a summary of institutional structures in Paris in the period, see Mark Everist, 'Struttura sociale e contesti artistici nell'opera francese (1806-64)', L'enciclopedia della musica Einaudi, 4 vols, ed. Jean-Jacques Nattiez (Turin: Einaudi, 2004) 4:956-975, English translation as 'Parisian Music Drama, 1806-64: Social Structures and Artistic Contexts', Giacomo Meyerbeer and $19^{\text {th }}$-Century Parisian Music Drama, Variorum Collected Studies Series CS805 (Aldershot: Ashgate, 2005), 1-18. 
${ }^{17}$ See Mark Everist, 'Theatres of Litigation: Stage Music at the Théâtre de la Renaissance, 1838-1840'. Cambridge Opera Journal 16 (2004), 133-161.

18 'Idem, 'Donizetti and Wagner: opéra de genre at the Théâtre de la Renaissance' Giacomo Meyerbeer and $19^{\text {th }}$-Century Parisian Music Drama, Variorum Collected Studies Series CS805 (Aldershot: Ashgate, 2005, 309-341)

${ }^{19}$ For Robin des bois, see idem, Music Drama at the Paris Odéon, 1824-1828 (Berkeley, Los Angeles and London: University of California Press, 2002), 252-271.

${ }^{20}$ The Théâtre-Lyrique's skill in manipulating the changing status of the licensing system is describing in idem, 'The Music of Power: Parisian Opera and the Politics of Genre, 18061864', Journal of the American Musicological Society 67 (2014) 715-720.

${ }^{21}$ The question of a state subvention for the Théâtre-Lyrique had been under discussion since the opera house was founded in the late 1840s. None was forthcoming until 1 January 1864 (Walsh, Second Empire Opera, 170).

${ }^{22}$ For Pasdeloup and the concert populaire, see Yannick Simon, Jules Pasdeloup et les origines du concert populaire, Symétrie recherche: Histoire du concert (Lyon: Symétrie, 2011), 90-99.

${ }^{23}$ The list of performances in Fauquet, 'Premières exécutions', 1303, however gives a false impression of the activity when all the performances, not just the premieres are taken into account. The season at the Concerts Populaires ran from mid-October to mid-March. For most of the 1860s Wagner was almost completely absent but the composer reached his greatest popularity in the 1868-69 and 1869-1870 seasons during each of which there were eight concerts including works by Wagner. In addition to the three works given by Wagner himself in 1860 were fragments from Die Meistersinger von Nürnberg, the overture to Rienzi and the Faust overture. See Appendix 1 for the frequency of these Wagner orchestral performances during Pasdeloup's tenure of the Thêatre-Lyrique.

${ }^{24}$ Simon, Jules Pasdeloup, 142. Pasdeloup had already programmed works by Wagner three times when he was directing the Société des jeunes artistes (February to April, 1861). Ibidem, 192 and 194.

${ }^{25}$ However inaccurate - and perhaps unfair - the slippage from Das Kunstwerk der Zukunft to la musique de l'avenir - it was a conventional epithet throughout the $1860 \mathrm{~s}$, together with light variation: le musicien de l'avenir, la musique dite de l'avenir, le prophète de l'avenir, système musical de l'avenir. Wagner himself complained about this move from Das 
Kunstwerk (which he translated as l'œuvre d'art) to musique as early as his '[Lettre sur la musique] à Monsieur Frédéric Villot', Quatre poèmes d'opéras traduits en prose française précédés d'une lettre sur la musique: le vaisseau fantôme, Tannhceuser, Lohengrin, Tristan et Iseult (Paris: Librairie Nouvelle; Bourdilliat, 1861) xx-xxi (the letter is dated 15 September 1860; ibidem, lxxiii). For Wagner, it was otherworldly: '... this spectre, so cleverly invented, of a 'music of the future'. This spectre has become so popular that it has been seen running like a ghost as far as French criticism' ('... ce spectre, si bien inventé, d'une 'musique de l'avenir'. Ce spectre est devenu si populaire qu'on l'a vu courir comme un revenant jusque dans des écrits français' (ibidem, xxi).

${ }^{26}$ One question surrounding the concerts of Wagnerian extracts towards the end of the $1860 \mathrm{~s}$ is whether or not Wagner's carefully-written introductions to the extracts from Tannhäuser and other works for the 1860 concerts were re-used for the later ones. The document is CONCERT / DE / RICHARD WAGNER / - / Dans l'impossibilité de faire entendre en entier ses opéras, l'auteur / se permet d'offrir au public quelques lignes d'explication qui lui / feront mieux comprendre le sens des morceaux détachés qu'il lui / soumet aujourd'hui / - PARIS / IMPRIMERIE DE D'AUBUSSON ET KUGELMANN / 13, Rue Grange-Batelière, 13. / - / 1860. Wagner's rationale for the publication was given on this title page: 'Given that it is impossible to have his operas heard in their entirety, the composer offers the public a few lines of explanation that will make them better understand the sense of the extracts that he proposes to them today'.

${ }^{27}$ In fact, as Ellis points out ('Wagnerism and Anti-Wagnerism', 76) Pasdeloup also held positions at the Concerts de l'Hôtel de Ville and the Orphéon municipal as well.

${ }^{28}$ The report is in Paris, Archives nationales (hereafter F-Pan) $\mathrm{F}^{21} 1121 / 4$.

${ }^{29}$ Table 1 is taken from the data provided in ibidem and in the contemporary press. Walsh, Second Empire Opera, 321-322 gives premieres only, not the revivals of Don Juan, La barbier de Séville, Le val d'Andorre nor La poupée de Nuremberg.

${ }^{30}$ See Mark Everist, Mozart's Ghosts: Haunting the Halls of Musical Culture (New York: Oxford University Press, 2012), 77-91

${ }^{31}$ Walsh, Second Empire Opera, 329. For La traviata at the Théâtre Italien, see Albert Soubies, Le Théâtre-Italien de 1801 à 1913 (Paris: Fischbacher, 1913), 156-158.

${ }^{32}$ Still the fullest biography of Ernest Guiraud is still Fétis, Biographie universelle, suppl. 1:436-438. 
${ }^{33}$ Ibidem, 2:41 and suppl. 1:115.

${ }^{34}$ Donizetti's L'ange de Nisida was repurposed as La favorite while the French translation of Das Liebesverbot as La défense d'amour was consigned to oblivion.

${ }^{35}$ See, however, the lightly inflected view of this question in John Deathridge, 'Rienzi... A Few of the Facts', Musical Times 124 (1983) 546-549

${ }^{36}$ Wagner worked on Schlesinger's piano-vocal scores and other arrangements for both works between 1840 and 1842, and wrote nothing short of a eulogy for La reine de Chypre in 'Bericht über eine neue Pariser Oper (La reine de Chypre von Halévy)', Abend-Zeitung [Dresden], 26 and 29 January 1842.

${ }^{37}$ Guilliaume (1825-1900) was the Secretary of the Conservatoire Royal de Musique in Brussels and a devotee of Wagner. He was also a playwright and translator who had collaborated with Gravrand on the Brussels translation of Verdi's Nabucco in 1848, and translated arias by Bach, Handel and Haydn into French in addition to his work on Rienzi. Wagner was anxious that Flaxland should have this score in Paris, and was dismayed to find that it was still not there as late as January 1869. See Wagner's letters to Charles Nuitter, 8 January 1869 and to Flaxland himself, 16 January 1869 (Meikle, ed., Briefe des Jahres 1869, 32-33 and 41).

${ }^{38}$ What appears to have happened, and what had added to Wagner's consternation about the text of Rienzi, is that two separate disturbances to his instructions took place. The first was that the Brussels score (the grande partition d'orchestre autographiée) seems to have been sold to Pasdeloup rather than passed to Flaxland as Wagner was hoping (see the letter from Wagner to Franz Schott where he asks for an explanation; 24 January 1869 [ibidem, 49-50]), and the second was that Flaxland had bought a copy of the score - with unauthorised cuts that Wagner did not want - from a source in Dresden, variously described as 'this vile music seller in Dresden' ('ce vil bouquiniste musical de Dresde') in a letter to Frances Flaxland, 4 February 1869 (ibidem, 57) and as the Kapellmeister in Dresden ('le Maitre chapelle de Dresde) in a letter to her husband, 28 February 1869 (ibidem, 97).

${ }^{39}$ Wagner declared the matter closed in his letter to Frances Flaxland, 4 February, 1869 (ibidem, 57).

${ }^{40}$ RIENZI / Opéra en 5 Actes / Poëme et Musique / DE / RICHARD WAGNER / Traduction Française de / Ch. NUITTER \& J. GUILLIAUME. / Partition Chant et Piano, / PARIS, / G. FLAXLAND Editeur, 4, Place de la Madeleine / Imp. Bertauts à Paris. 
${ }^{41}$ RIENZI / Opéra en 5 Actes / Poëme et Musique / DE / RICHARD WAGNER / Traduction Française de / Ch. NUITTER \& J. GUILLIAUME. / Partition Chant et Piano, / Paris.

DURAND \& SCHCENWERK Editeurs / 4. Place de la Madeleine 4. Durand-Schœnwerk took over Flaxland's business on 30 December 1869 (Anik Devriès and François Lesure, Dictionnaire des éditeurs de musique français, 2 vols [vol. 1 in 2 parts], Archives de l'édition musicale française 4 (Geneva: Minkoff, 1979-88) 2:151).

${ }^{42}$ RIENZI / der Letzte der Tribunen. / GROSSE TRAGISCHE OPER IN 5 ACTEN / von / Richard Wagner / - / Partitur / Als Manuscript autographiert / - Konigl. Schs. HofLithographie - \& Steindruckerei von Fürstenau \& $C^{\circ}$ Dresden \& Leipzig.

${ }^{43}$ The published libretto is BIBLIOTHÈQUE SPÉCIALE DE LA SOCIÉTÉ / DES / AUTEURS ET COMPOSITEURS DRAMATIQUES / . . / RIENZI / OPÉRA EN CINQUE ACTES / PAROLES ET MUSIQUE / DE RICHARD WAGNER / TRADUCTION FRANÇAISE DE MM. / CH. NUITTER ET JULES GUILLIAUME / PARIS / LIBRAIRIE DRAMATIQUE / 10, RUE DE LA BOURSE, 10 / - / 1869. The censors' libretto is F-Pan $\mathrm{F}^{18} 738$.

${ }^{44}$ Ibidem, [5].

${ }^{45}$ Ibidem, [6].

${ }^{46}$ RIENZI / OPÉRA EN CINQUE ACTES, 6-7.

${ }^{47}$ F-Pan $\mathrm{F}^{18} 738,[6]$.

${ }^{48}$ Ibidem.

${ }^{49}$ For a summary of French engagement in Italy, and especially in Rome at the end of the 1860s, see Sylvie Le Ray-Burimi, Anthony Petiteau, Monica Maffioli and Marina Messina, eds, Naissance d'une nation: Napoléon III et l'Italie, 1848-1870: catalogue d'exposition, Musée de l'Armée du 19 octobre 2011 au 15 janvier 2012 (Paris: Nicolas Chaudun, 2011).

50 'RIENZI / OPÉRA EN 5 ACTES / Partition des Chœurs'. F-Pn MAT TH- 513.

${ }^{51}$ Bar numbers refer to the edition of the piano-vocal score: Richard Wagner: Rienzi, der Letzte der Tribunen, große tragsiche Oper in fünf Akten, ed. Karl Klindowrth and Egon Voss (Mainz, etc.: Schott, [1982]) and to the critical edition, Reinhard Strohm and Egon Voss, eds, Richard Wagner: Rienzi, der Letzte der Tribunen. Große tragische Oper in 5 Akten, 5 vols, Sämtliche Werke 3 (Mainz, etc.: Schott, 1974-1977). 
${ }^{52}$ RIENZI / . . . Konigl. Schs. Hof-Lithographie - \& Steindruckerei von Fürstenau \& $C^{o}$ Dresden \& Leipzig.

${ }^{53}$ RIENZI / Opéra en 5 Actes / ... / PARIS, / G. FLAXLAND Editeur, 4, Place de la Madeleine / Imp. Bertauts à Paris. The missing bars should follow at 294.

${ }^{54}$ RIENZI / Opéra en 5 Actes / ... / Paris. DURAND \& SCHCNWERK Editeurs / 4. Place de la Madeleine 4, 294-306

${ }^{55}$ Revue et Gazette musicale de Paris, 11 April 1869.

${ }^{56}$ Le temps, 13 April 1869.

${ }^{57}$ La chronique illustrée, 11 April 1869.

${ }^{58}$ Bars 217-252.

${ }^{59}$ Bars 246-286.

${ }^{60}$ Bars $649-787$ and 826-958.

${ }^{61}$ Bars 33-57. This in addition to the removal of the ambassadors' vocal lines later in the number (for which see below 000-000).

${ }^{62}$ Ibidem, 72-74. The letter was published in La liberté, 7 April 1869.

63 'Cependant ma présence et ma participation à la représentation qui se prépare, devraient donner lieu à un malentendu. J'aurais l'air de me mettre à la tête d'une entreprise théâtrale, dans le but de regagner par Rienzi ce que j'ai perdu par Tannhäuser; c'est du moins ainsi, sans nul doute, que la presse interpréterait ma venue', ibidem.

64 'Quand M. Pasdeloup est venu me dire qu'il prenait la direction du Théâtre-Lyrique dans l'intention de donner plusieurs de mes ouvrages, je ne crus pas pouvoir refuser à cet ami zélé et capable l'autorisation de les représenter, et, comme il désirait débuter par Rienzi, je lui dis qu'en effet c'était celui de mes opéras qui m'avait toujours paru devoir s'adapter le plus aisément à une scène française', ibidem.

${ }^{65}$ Quatre poèmes d'opéra, xlvii. Wagner's view of the generic nature of Rienzi had not always been thus, however. In a letter dated 12 November 1838 to the author and editor, August Lewald, he stressed the essentially Germanic nature of the opera. See Wilhelm Altman, ed., Richard Wagners Briefe, 2 vols (Leipzig: Bibliographisches Institut, 1925), 1:59-64, especially 63. In this, however, Wagner was aligning Rienzi with Meyerbeer's 1836 Les Huguenots, as he would in his essay on the opera, 'Über den Standpunkt der Musik 
Meyerbeers', of 1840. See Richard Wagner, 'Über Meyerbeers Hugenotten', Sämtliche Schriften und Dichtungen: Volks-Ausgabe, 12 vols [in 6 Auflage] (Leipzig: Breitkopf und Härtel, 1911-1914), 12:22-30. See the translation and commentary in Thomas Grey, 'Wagner Admires Meyerbeer (Les Huguenots)', Richard Wagner and His World, ed. Thomas Grey (Princeton and Oxford: Princeton University Press, 2009), 335-346.

66 'Pour être bref, je voudrais au contraire, que vous trouviez le temps de me rejoindre accompagné de Votre Régisseur - pour un jour. Je voudrais voir les dessins des décors et des costumes, - puis m'entendre, le libretto à la main, avec le régisseur pour toutes les spécialités de la mise en scène, et enfin avec Vous (je pense que Vous dirigez l'orchestre?) ou avec Votre chef du chant, parcourir la partition, pour donner mes avis pour les tempi, et pour tout ce qui serait à communiquer de ma part'. Letter from Wagner to Pasdeloup, 25 February 1869 (Mielke, ed., Briefe des Jahres 1869, 87).

67 'Encore, et toujours encore! Ecoutez moi! Venez pour une simple journée - car moi - venir à Paris? C'est une affaire d'une sorte de conséquences - peut-être - désastreuses pour nous deux! - C'est pour cela que je répète toujours: Venez me voir et - laissez-moi en paix à Lucerne! -‘. Letter from Wagner to Pasdeloup, 12 March 1869 (ibidem, 112).

${ }^{68}$ Letter from Wagner to Hans von Bülow, 18 March 1869 (ibidem, 116-117). The fact that Pasdeloup was amusing presumably did not change Wagner's view that he was 'reckless, like all Frenchmen' ('leichtsinnig, wie alle Pariser'). Letter from Wagner to Édouard Schuré, 23 January 1869 (ibidem, 45).

${ }^{69}$ The formulation is found in a letter from Wagner to Charles Nuitter, 16 April 1869 (ibidem, 146).

${ }^{70}$ See Philippe Reynal, ‘Sur les pas de Charles Nuitter', Richard et Cosima Wagner - Charles Nuitter; Correspondence, ed. Peter Jost, Romain Feist and Philippe Reynal (Sprimont:

Mardaga, 2002), 9-27.

${ }^{71}$ Ibidem, 24-25.

${ }^{72}$ See above, 000-000.

${ }^{73}$ Letter from Wagner to Schott, 20 July 1869 (Mielke, ed., Briefe des Jahres 1869, 209).

${ }^{74}$ Descriptions of the augmentation of the Théâtre-Lyrique's establishment were common. See for example, L'art musical, 8 April 1869. 
${ }^{75}$ See 'Monjauze, Jules-Sébastien, Karl-Josef Kutsch and Leo Riemens, Großes

Sängerlexikon, 4 vols (Bern and Stuttgart: Francke, 1987-1994; $4^{\text {th }}$ edn, 7 vols, Munich: Saur, 2003) 4:2411-2412.

${ }^{76}$ See Hippolyte Prévost's review in La France politique, scientifique et littéraire, 8 April 1869.

77 ، ...un très bel air que Monjauze chante en grand artiste; car [']à tout seigneur tout honneur['], Monjauze a été le héros de la soirée; il a mis à ce Rienzi toute son ardeur, toutes son âme; il a eu des moments magnifiques', L'illustration, 10 April 1869. The quotation is from Romans, 13:7.

78 'Enfin, au commencement du cinquième acte, arrive pour nous reposer un morceau que l'ouverture nous a déjà fait connaître, la ravissante prière d'une facture si large, d'un sentiment si élevé et si touchant. Hélas! il est trop tard, trop tard pour nous dont la puissance auditive est à bout, trop tard pour l'artiste, dont la voix, ébranlée par un fortissimo de quatre actes, n'a plus le calme nécessaire pour se poser doucement sur les notes, et tremble et vacille, au lieu de caresser avec suavité les contours de la mélodie', Le correspondent, 10 May 1869. 79 'The role of the tribune is crushing, and it is to be feared that Monjauze's voice, a voice of slightly cracked metal, does not eventually succumb to the enormous expenditure of sonority that the role requires' ('Le rôle du tribun est écrasant, et il est à craindre que la voix de Monjauze, voix d'un métal un peu fêlé, ne succombe à la longue aux dépenses de sonorité énorme que le rôle exige'), La presse, 12 April 1869 (unsigned).

80 'Monjauze was magnificent in the role of Rienzi. His lively, incisive and mordant pronunciation magisterially throws the character of the tribune into relief. He has understood Wagner, and - in a word - he is worthy of playing Le Tannhauser' ('Montjauze a été magnifique dans le rôle de Rienzi. Sa prononciation vive, incisive, mordante donne un relief magistral au personnage du tribun. Il a compris Wagner, et - pour tout dire en un mot - il est digne de jouer Le Tannhauser'), La chronique illustrée, 11 April 1869.

${ }^{81}$ See Johannès Weber, 'Monjauze is a fine Rienzi; he would be an even finer one if he moderated and managed his gestures to avoid all semblance of vulgarity. He delivered the prière and certain recitatives, but he seeks only and continuously the effects of energy in his vocal outbursts' ('Monjauze est un beau Rienzi; il en serait encore un plus beau s'il économisait et réglait ses gestes pour éviter toute apparence de vulgarité. Il a très bien dit sa prière et certains récitatifs, mais il cherche uniquement et continuellement les effets d'énergie dans les éclats de voix'), Le temps, 13 April 1869. 
${ }^{82}$ See, among others, La patrie, 12 April 1869, (Achille-Théodore-Barthélemy LauzièresThémines). Very little is known about Anna Sternberg. She figures in no standard biobibliography, and even in contemporary documents is referred to as Sternberg, Steinberg and Sternberger. Other members of the cast who came in for praise were Juliette Borghèse (Adriano), Alfred Giraudet (Colonna) and Marguerite Priola (le Messager de la Paix), who would go on to a stellar but tragically short-lived career at the Opéra-Comique. See KutschRiemens, Großes Sängerlexikon, 4:2810.

${ }^{83}$ See above, 000-000.

${ }^{84}$ See Mark Everist, 'Partners in Rhyme: Alphonse Royer, Gustave Vaëz, and Foreign Opera in Paris during the July Monarchy', Fashions and Legacies of Nineteenth-Century Italian Opera, ed. Roberta Montemorra Marvin and Hilary Poriss (Cambridge: Cambridge University Press, 2010), 30-52, esp. 39-40. See also idem, 'Rossini at the Paris Opéra, 18431847: Translation, Arrangement, Pasticcio', Librettoübersetzung: Interkulturalität im europäischen Musiktheater, ed. Herbert Schneider and Rainer Schmusch,

Musikwissenschaftliche Publikationen 32 (Hildesheim: Olms, 2009) 131-163, esp. 149-157.

${ }^{85}$ This is an important element in the dynamic surrounding Le Tannhauser in 1861. See Turbow, Art and Politics, 142-149.

${ }^{86}$ See Jeffrey Cooper, The Rise of Instrumental Music and Concert Series in Paris, 18281871, Studies in Musicology 65 (Ann Arbor, Mich.: UMI Research Press, 1983), 243, 259 and 270. See also William Weber, 'How Wagner's Music Became Canonic in Public Concerts', Canon, the Press and the Public: Essays on French Music from Lully to Wagner (forthcoming); I am grateful to Prof. Weber for making the text of this article available to me in advance of publication.

${ }^{87}$ This paragraph is based on Clair Rowden, 'Parodying opera in Paris: Tannhäuser on the popular stage, 1861', in Anne Kauppala, Jens Hesselager and Ulla-Britta Broman-Kananen (eds.), Tracing Operatic and Theatrical Performances in the Long 19th Century (Helsinki: Sibelius Academy, 2016). I thank Professor Rowden for making a copy of the article available to me before publication.

${ }^{88}$ Weber ('How Wagner's Music Became Canonic') points to the performative environment for many of these works. 
${ }^{89}$ Auguste de Gasparini, Étude publié par Le ménestrel: La nouvelle Allemagne musicale (Paris: Heugel 1866). For the analysis of the sources of the book, and their dates, see Ellis, ('Wagnerism and Anti-Wagnerism', 64, note 45).

${ }^{90}$ See Maxime Leroy, Les premiers amis français de Wagner (Paris: Albin Michel, 1925), 137. Ellis seems to agree with the view, however ('Wagnerism and Anti-Wagnerism', 66). ${ }^{91}$ Ibidem, 68-70.

${ }^{92}$ Mendès' Revue fantaisiste ran from 15 February 1861 to 1 November 1861 . Wagner was a collaborator (Charles Bataille, 'Revue de la quinzaine', Revue fantaisiste, 1 March 1861 [1 (1861), 183-184]), and Gasparini wrote a report on the dress-rehearsal of Le Tannhauser that - despite his promise - the author never followed up (Gasparini, 'Revue musicale', Revue fantaisiste, 1 March 1861 [1 (1861), 195-196). Apart from a few tangential asides, there was very little about the composer, and Mendès himself wrote nothing on the subject.

${ }^{93}$ Journal Officiel, 12 April 1869.

${ }^{94}$ Le ménestrel, 18 April 1869.

95 '[Le public] a assisté l'arme au bras, indifférent, tranquille, inoffensif aux enthousiasmes de commande et de clocher de toute une escouade de wagnéristes de bonne ou de mauvaise foi, venus au théâtre pour applaudir quand même. Le public parisien les a laissé faire, en souriant de dédain et en haussant les épaules, sans même se donner la peine de demander à ces applaudisseurs embrigadés s'il y avait de la pudeur, de la dignité, à applaudir cette musique hybride, cette œuvre indigeste, faite tout entière de cris d'énergumènes et de tapage infernal', L’art musical, 8 April 1869.

96 'imiter servilement certaine musique italienne' (ibidem).

${ }^{97} \mathrm{He}$ described Rienzi as a work of Wagner's 'première manière', and went on to say that 'The hand of Marschner guides him, the breath of Weber arouses him; although a slightly revolutionary pupil, at this early hour of renown and glory, he prides himself still to be the follower of the author of Der Vampyr and the siren of Oberon' ('La main de Marschner le guide, le souffle de Weber l'élève; quoique disciple un peu révolté, à cette première heure de la renommée et de la gloire, il s'enorgueillit encore d'être le suivant de l'auteur du Vampire et du chantre d'Obéron'), La presse, 12 April 1869.

98 'une individualité puissante, vigoureuse et originale ... la main exercée et hardie d'un compositeur appelé à devenir lui aussi, un grand maître', Journal des débats, 18 April 1869. 
99 'Dans Rienzi comme dans Lohengrin, le souffle héroïque et chevaleresque d'Euryanthe se fait particulièrement sentir', ibidem.

100 'Il paraît pourtant que ce Rienzi est une œuvre de jeunesse de M. Wagner, un timide essai, un croquis fugitif, un rien... Grand merci! Ce n'est pas, il est vrai, que nous prétendions que Rienzi ressemble au Tannhoeser [sic] de grinçante mémoire; on y trouverait plutôt (oh! étonnement!) des infiltrations de style italien, La vie parisienne, 10 April 1869.

101 'Le vrai Wagner, le révolutionnaire, l'ogre de Weimar, n'est pas ainsi fait; en un mot Lohengrin est cent fois plus mélodique que Rienzi!', Le ménestrel, 18 April 1869.

${ }^{102}$ La patrie, 5 April 1869.

103 'un éternel récit; le vieux récit, le traditionnel entendez-vous, interrompant souvent ses périodes par la cadence italienne, sur la tonique et la dominante, immédiatement suivie dans l'orchestre, des deux accords de dominante et de tonique', Le ménestrel, 18 April 1869. ${ }^{104}$ This was dramatised in an exchange between François-Henri-Joseph Blaze (Castil-Blaze) and Hector Berlioz in the late 1820s. See Mark Everist, 'Gluck, Berlioz and Castil-Blaze', Reading Critics Reading: French Music Criticism, 1789-1848, ed. Mary Ann Smart and Roger Parker (Oxford: Oxford University Press, 2001), 86-108.

105 ‘....Rienzi; cet opéra ou l'on trouve le feu, l'éclat que cherche la jeunesse, est celui qui m'a valu en Allemagne mon premier succès, non-seulement au théâtre de Dresde ou je l'ai fait représenter pour la première fois, mais depuis lors sur une grande partie des théâtres ou il est donné avec mes autres opéras. Cet ouvrage a été conçu et exécuté sous l'empire de l'émulation excité en moi par les jeunes impressions dont m'avaient rempli les opéras héroïques de Spontini et le genre brillant du Grand-Opéra de Paris, d'ou m'arrivaient des ouvrages portant les noms d'Auber, de Meyerbeer et d'Halevy', Wagner, 'Lettre sur la musique', xlvii.

${ }^{106}$ Wagner's essay 'Bellini: ein Wort zu seiner Zeit' was either a response to performances of Norma in Königsberg in March 1837 or a pre-performance text for a production in Riga, and was published in Der Zuschauer, 7 December 1837. See David Trippett, 'Excursus: Bellini's Sinnlichkeit and Wagner's Italy', Wagner's Melodies: Aesthetics and Materialism in German Musical Identity (Cambridge: Cambridge University Press, 2013), 182-197. For earlier accounts of Wagner's response to Italian opera, see Thomas Grey, 'Musical Background and Influences', The Wagner Compendium: A Guide to Wagner's Life and Music, ed. Barry Millington (London: Thames and Hudson: 1992), 64-102, especially the revealing table of Wagner's knowledge of Italian - and especially French - works in the 1830s (ibidem, 69-70). 
${ }^{107}$ See Ernest Reyer, for example, who wrote that 'Anyway, these cavatinas, these bravura arias and these outdated formulas do not displease the public at all; its ear has been used to them for a long time; everywhere they are encountered, the public welcomes them warmly and greets them like old acquaintances' ('D'ailleurs, ces cavatines, ces airs de bravoure et ces formules surannées ne lui déplaisent point; son oreille y est depuis longtemps habituée; partout où il les rencontre, il leur fait bon accueil et les salue comme de vieilles connaissances'), Journal des débats, 18 April 1869.

${ }^{108}$ Revue et Gazette musicale de Paris, 11 April 1869.

109 'A l'époque où Richard Wagner écrivit Rienzi, Meyerbeer avait déjà établi, et l'on sait avec quel succès, une fusion entre l'élément germanique et l'élément italien; l'exemple du maître séduisit d'autant plus facilement le jeune compositeur, que celui-ci destinait son œuvre à notre première scène lyrique, pensée ambitieuse s'il en fût!', Journal des débats, 18 April 1869.

${ }^{110}$ Pour en finir avec la partition de Rienzi, disons, en un mot, que c'est le Crociato de Wagner, une œuvre encore indécise où l'on sent que le maître n'a pas encore trouvé sa voie, mais où l'on devine déjà dans les tentatives de l'enfant l'étoffe du chercheur', La patrie, 5 April 1869.

${ }^{111}$ L'art musical, 8 April 1869.

112 'However, while waiting for a Damascene conversion, Wagner would have good need of the miracle at Cana; since, really, he smells his best wine first, and the first two acts of Rienzi appeared to me far superior to the last three' ('Toutefois, en attendant le miracle de Damas, Wagner aurait eu bon besoin de celui de Cana; car, vraiment, il sent tout d'abord son meilleur vin, et les deux premiers actes de Rienzi m'ont paru fort supérieurs aux trois derniers'), Le correspondant, 10 May 1869.

${ }^{113}$ See John Deathridge, Wagner's 'Rienzi': A Reappraisal Based on a Study of the Sketches and Drafts (Oxford: Clarendon Press, 1977), 40, and passim, for an account of the change in musical style between the second and third acts of Rienzi as a result of work on Der fliegende Holländer.

${ }^{114}$ Richard Wagner, Das Judenthum in der Musik (Leipzig: Weber, 1869). It is reprinted with a wide range of complementary texts in Jens Malte Fischer, Richard Wagners 'Das Judenthum in der Musik': eine kritische Dokumentation als Beitrage zur Geschichte des 
Antisemitismus, insel taschenbücher 2617 (Frankfurt am Main: Insel, 2000), 139-196. This new edition was published in early March 1869.

${ }^{115}$ For an exhaustive study of early French translations of Das Judenthum in der Musik, see Peter Bloom, 'The French Text of Wagner's Das Judenthum in der Musik', Notes: Quarterly Journal of the Music Library Association 67 (2010), 263-283. Escudier's earlier translation had carried the title 'Les juifs musiciens'.

${ }^{116}$ The summary of all four parts of the Ring of the Nibelungen was published on 13 July, 6 , 13 and 20 September 1863 in the Revue et Gazette musicale de Paris by Henri-Joseph-Maria Duesberg and $\mathrm{S}^{* * * *}$. Given the negative comments interspersed in the summary, this is unlikely to be Schuré. Editorial candidates are Edouard Déaddé, writing as Saint-Yves, or Désiré-Guillaume-Edouard Monnais, writing as Paul Smith. See Ellis, Music Criticism in Nineteenth-Century France: La Revue et Gazette Musicale de Paris, 1834-80 (Cambridge: CUP, 1995), [252-253].

${ }^{117}$ Le nain jaune, 7 June 1865.

${ }^{118}$ Ibidem, 24 June 1865.

${ }^{119}$ This was a French translation of the original version of the text (that is, without Wagner's March 1869 introduction): LE JUDAÏSME / DANS LA MUSIQUE / PAR / RICHARD WAGNER / (Extrait du Guide Musical) / BRUXELLES / IMPRIMERIE DE J. SANNES, / rue Montagne-des-Aveugles, 15 / - / 1869, based on a translation published in the Brussels Guide musical and made by none other than Jules Guilliaume, the original translator of the Rienzi libretto.

120 'Wagner, qui remplit l'Allemagne du bruit de son nom et la salle du Théâtre-Lyrique du tapage de sa musique, se croit poursuivi par les juifs; c'est la conspiration de Judas contre sa personne; il le dit, il le proclame; ce rôle de martyr est si propre au succès! Que fait tout cela, et qu'avons-nous besoin de le savoir?', L'illustration, 10 April 1869.

121 'Voilà comment Wagner apprécie les compositions sublimes d'un homme de génie que l'univers a salué de ses acclamations, dont la mort a grandi même la renommée. Ainsi les Huguenots, ce chef-d'œuvre de l'esprit humain en musique, dont chaque note est gravée sur l'airain avec une pointe en diamant, sont comme non avenus, absolument comme Guillaume Tell, aux yeux de cet insensé, de ce monomane, de ce nouvel Erostrate, de ce fanatique destructeur: il essaye de porter la torche dans le temple du Goût, dans le sanctuaire duquel il 
n'a pu encore déposer aucune de ses œuvre de théâtre, après avoir essayé en vain d'en ébranler les colonnes de marbre et de granit', La France, 8 April 1869.

${ }^{122}$ Le Figaro, 4 April 1869; La chronique illustrée, 11 April 1869

123 ‘Au pupitre, M. Pasdeloup s'était installé comme un général en chef qui va livrer la grande bataille d'où peut dépendre tout l'avenir. Son armée renforcée se tenait au port d'arme, avec des réserves prêtes dans la coulisse, canons braqués et flamberge au vent', Le siècle, 13 April 1869.

124 'Et comment en eût-il été autrement? Comment cette grande et mémorable bataille ne se serait-elle pas terminée par la plus éclatante des victoires, lorsque, sous la conduite d'un directeur expérimenté et consciencieux, tout ce que la grande armée de l'Opéra compte de soldats éprouvés combattait, et avec quel dévouement, quel enthousiasme!', La nouvelle Minerve 4 (1836), 328 (Édouard Lemoine).

125 'Enfin on allait prendre une éclatante revanche: après le Tannhäuser on aurait Rienzi, pour effacer le Sadowa de M. Wagner', Le siècle, 13 April 1869.

${ }^{126}$ The complex exchanges and playing out of power politics in Bavaria, and Wagner's role in them, is described in Hannu Salmi, 'Die Herrlichkeit des deutschen Namens..... ': Die schriftstellerische und politische Tätigkeit Richard Wagners als Gestalter nationaler Identität während der staatlichen Vereinigung Deutschlands, Annales universitatis turkuensis (Turku: Turun Yliopisto, 1993), 193-207.

${ }^{127}$ Otto Strobel, ed., König Ludwig II. und Richard Wagner. Briefwechsel. Mit vielen anderen Urkunden ... mit 16 Handschriftennachbildungen und 16 Bildbeilagen, 5 vols (Karlsruhe: Braun, 1936-1939) 2:26-83 contains the key exchanges between Wagner and the King in the summer of 1866 .

128 'Qu'on montre ce portrait à une personne à qui les traits des célébrités contemporaines sont mal connus, qu'on lui dise qu'il représente un des hommes qui ont le plus agité l'Allemagne dans ces derniers temps, et il y a beaucoup à parier qu'elle nommera $\mathrm{M}$. de Bismarck avant de songer à Wagner', Le français, 5 April 1869.

129 'Two proclamations, two expeditions, two rebellions, two betrayals, a procession, a burial, a curse, an excommunication, the whole crossed by an ice-cold little love-affair and crowned by a collapse and a conflagration.... Now, that will soon succeed beyond the Rhine! There, Bismarck's disingenuousness is well endured' ('Deux proclamations, deux expéditions, deux insurrections, deux trahisons, une procession, une inhumation, une malédiction, une 
excommunication, le tout traversé par une amourette à pierre fendre et couronné par un écroulement et un incendie.... Or, cela réussit au-delà du Rhin, à la bonne heure! On y supporte bien le sans-façon de M. de Bismark!'), Le correspondent, 10 May 1869.

${ }^{130}$ William E. Echard, 'Conference Diplomacy in the German Policy of Napoleon III, 18681869', French Historical Studies 4 (1966), 241-242.

${ }^{131}$ Les Origines diplomatiques de la guerre de 1870-1871, 29 vols (Paris: Ficker, 1910-1932) 19:310, note 2 .

${ }^{132}$ Lawrence D. Steefel, Bismarck, The Hohenzollern Candidacy, and the Origins of the Franco-German War of 1870, (Cambridge, Mass.: Harvard University Press, 1962), 14, note 10.

${ }^{133}$ The expression comes from Charles Dickens. See his 'The Cupboard Papers VII; The Sweet Art', All the Year Round, 20 November 1872.

${ }^{134}$ See above, note 000 .

${ }^{135}$ RIENZI / OPÉRA EN CINQUE ACTES, 48.

${ }^{136}$ Ibidem.

${ }^{137}$ Rienzi, act ii finale (no. 7), bars 128-191

${ }^{138}$ F-Pan $\mathrm{F}^{18} 738$, [26].

${ }^{139}$ See Marian Smith, 'Processions in French Grand Opera', Symposium: Moving Meyerbeer: Musiktheater im Brennpunkt von Bild und Bewegung, Swiss Opera Studio, Bern, 24-25 April 2015. 
Everist Table 1

\begin{tabular}{|c|c|c|c|c|}
\hline Composer & Title & Premiere & T-L Premiere & Other Paris Premiere \\
\hline Gluck & Iphigénie en Tauride & 1779 & 1868 & $1779(\mathrm{O})$ \\
\hline Mozart & Don Juan & 1787 & 1866 & $1811(\mathrm{TI})$ \\
\hline Méhul & L'irato & 1801 & 1868 & $1801(\mathrm{OC})$ \\
\hline Rossini & Le barbier de Séville & 1816 & 1851 & 1819 (TI) \\
\hline Adam & Le brasseur de Preston & 1838 & 1868 & 1838 (OC) \\
\hline Wagner & Rienzi & 1842 & 1869 & \\
\hline Halévy & Le val d'Andorre & 1848 & 1860 & 1848 (OC) \\
\hline Adam & La poupée de Nuremberg & 1852 & 1852 & \\
\hline Verdi & Violetta & 1853 & 1864 & $1856(\mathrm{TI})$ \\
\hline Guiraud & En prison & 1869 & 1869 & \\
\hline Boulanger & Don Quichotte & 1869 & 1869 & \\
\hline
\end{tabular}


Everist Table 2

\begin{tabular}{lll}
\hline Gesandte & Key & Scoring \\
\hline Milan & E major & Bass \\
Lombardy & G major & Tenor and Bass \\
Naples & G major & Tenor \\
Bohemia and Bavaria & E major & Two basses in unison
\end{tabular}


Everist Appendix 1

1868-69 season (18 October 1868 to 4 April 1869) [Bernard, 2:22-24]

18 October 1868

25 October 1868

15 November 1868

6 December 1868

10 January 1869

24 January 1869

21 March 1869

4 April 1869
Fragments des Maîtres-Chanteurs

Entr'acte des Maîtres-Chanteurs

Ouverture de Tannhauser

Prélude de Lohengrin

Marche réligieuse de Lohengrin

Ouverture de Rienzi

Marche et Chœur des fiançailles de Lohengrin

Marche et Chœur des fiançailles de Lohengrin

1869-70 season (17 October 1869 to 15 April 1870) [Bernard, 2:25-27]

14 November 1869

20 November 1869

12 December 1869

19 December 1869

2 January 1870

23 January 1870

6 March 1870

20 March 1870
Marche religieuse de Lohengrin

Ouverture de Tannhauser

Ouverture des Maitres-Chanteurs

Ouverture des Maîtres-Chanteurs

Prélude de Lohengrin

Ouverture du Vaisseau-Fantôme

Ouverture de Faust

Ouverture de Tannhauser 